\title{
Ore-forming fluids of the Fancha gold deposit, Lingbao, Henan Province
}

\author{
Zhang $\mathrm{Yu}^{1 *}$, Cao $\mathrm{Yi}^{2}$ and Li Hongmeng ${ }^{2}$ \\ ${ }^{1}$ China University of Geosciences (Beijing), School of Ocean Sciences, 100083 Beijing, P.R.China; (zhangyu_cugb@foxmail.com) \\ ${ }^{2}$ China University of Geosciences (Beijing), School of Earth Sciences and Resources, 100083 Beijing, P.R.China
}

doi: $10.4154 / g c .2019 .22$

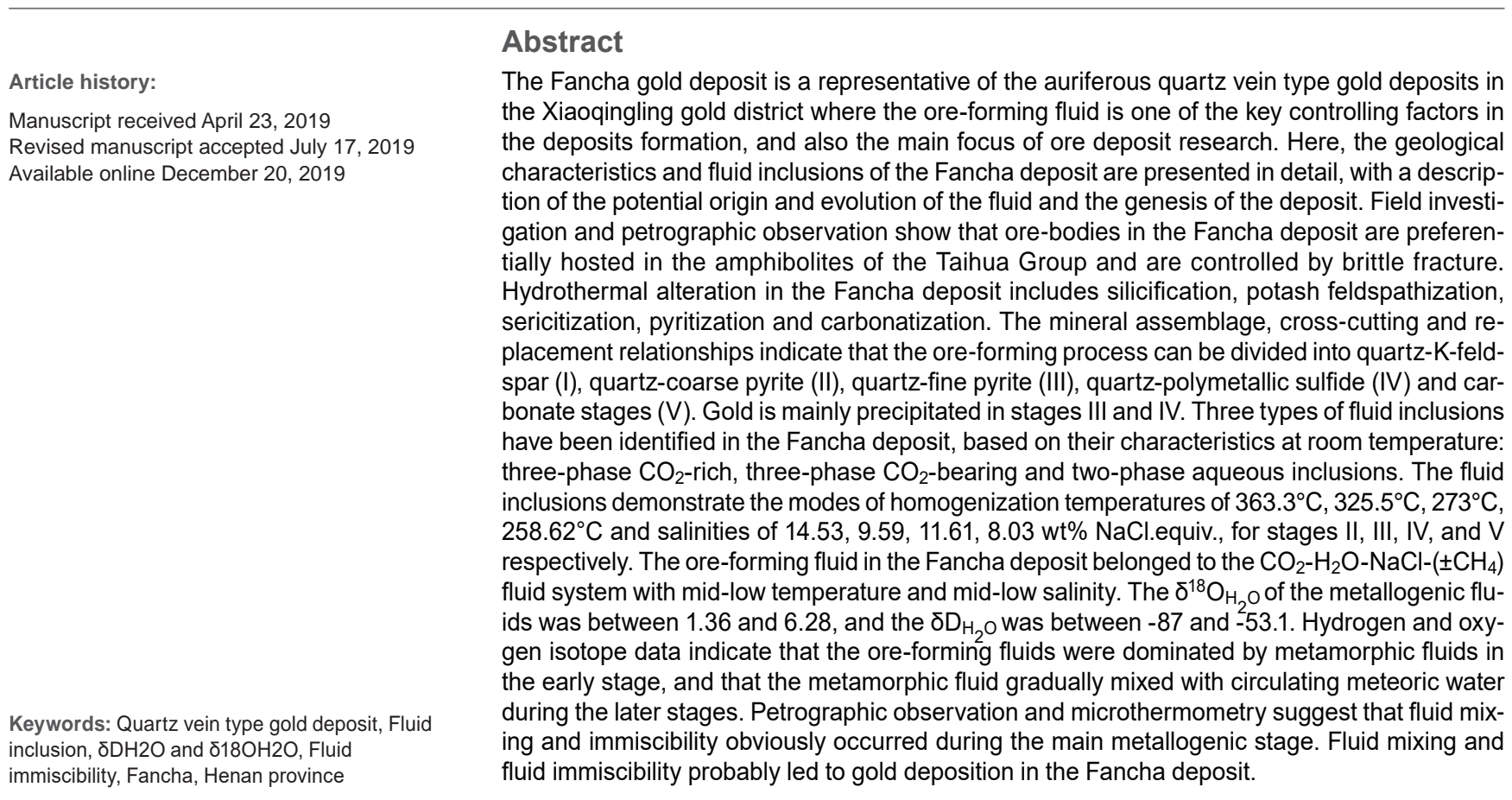

\section{INTRODUCTION}

The Xiaoqinling gold deposit area is an important rock gold producing areas in China (CHEN et al., 1998; FAN et al., 2000a; MAO et al., 2002; WANG et al., 2010). Although the area has been the subject of a great deal of investigative research, the way in which the gold deposits formed here is still debated. In Xiaoqinling, the primary type of deposit is quartz vein gold of which the Fancha gold is a typical example (LI et al., 1996; REN, 2012; ZHOU et al., 2014). Research on the Fancha gold deposits can therefore, not only potentially identify the metallogenic formation mechanism of such deposits, but also provide critical theoretical support for the mineral exploration of the area.

Previous studies have investigated the ore-forming fluids of the gold deposits in the area (CHEN et al., 2007; FAN et al., 2003; LI et al., 2012b; MAO et al., 2002; ). The phases of the inclusions in the current gold deposits are three-phase $\mathrm{CO}_{2}$-rich, three-phase $\mathrm{CO}_{2}$-bearing, two phase aqueous, liquid, vapours, and threephase daughter mineral-bearing inclusions (ZHAO et al., 2017; ZHOU et al., 2015). Currently the main theories on the origins of the ore-forming fluids include: (1) metamorphic fluids (WANG and ZHOU, 1996), (2) magmatic fluids (NIE et al., 2001), (3) deep mantle fluids (LU et al., 2003), and (4) mixed fluids (CHEN et al., 2007). Regarding the ore fluid evolution, there are generally two theories: (1) magmatic water gradually evolves into meteoric wa- ter (FAN et al., 2000a; FAN et al., 2000b), and (2) metamorphic water gradually evolves into meteoric water (QI et al., 2002). There are also various views on the ore sources from: (1) mesozoic granites (NIE et al., 2001; ZHAO et al., 2017), (2) the Taihua group (FENG et al., 2014; LI et al., 1996), (3) mainly the centrosphere, and a small proportion from the wall rock (LU et al., 2003), and (4) a multi-material source (CHEN et al., 2007).

The placement of basic dykes in Xiaoqinling reflects the tectonic setting of the crustal extension. The lithology is mainly diabase and lamprophyre, which are spatially related to the goldbearing quartz vein (CHEN et al., 2008; LUAN et al., 1985; ZHANG et al., 2009a). Presently, in terms of the relationship between these two, there is debate: LI et al. (1996) considered that the basic dykes provide a material source for gold mineralization, while CHEN et al. (1998), LI et al. (2012a), LI et al. (2012b) challenged this theory. In addition, some scholars believe that the volatiles in the lamprophye mainly act as mineralizers (NI, 1994).

Fluid inclusions can preserve various geological and geochemical information during mineralization. Therefore, conducting a detailed physico-chemical and thermodynamic study of fluid inclusions can yield important data on the mineralization process, which may also inform and guide prospecting and exploration (LU, 2004; MELFOS et al., 2016; ROEDDER, 1984; TASEV et al., 2018). Therefore, our main objective focused on studying the Fancha gold deposits, and in particular, thoroughly 

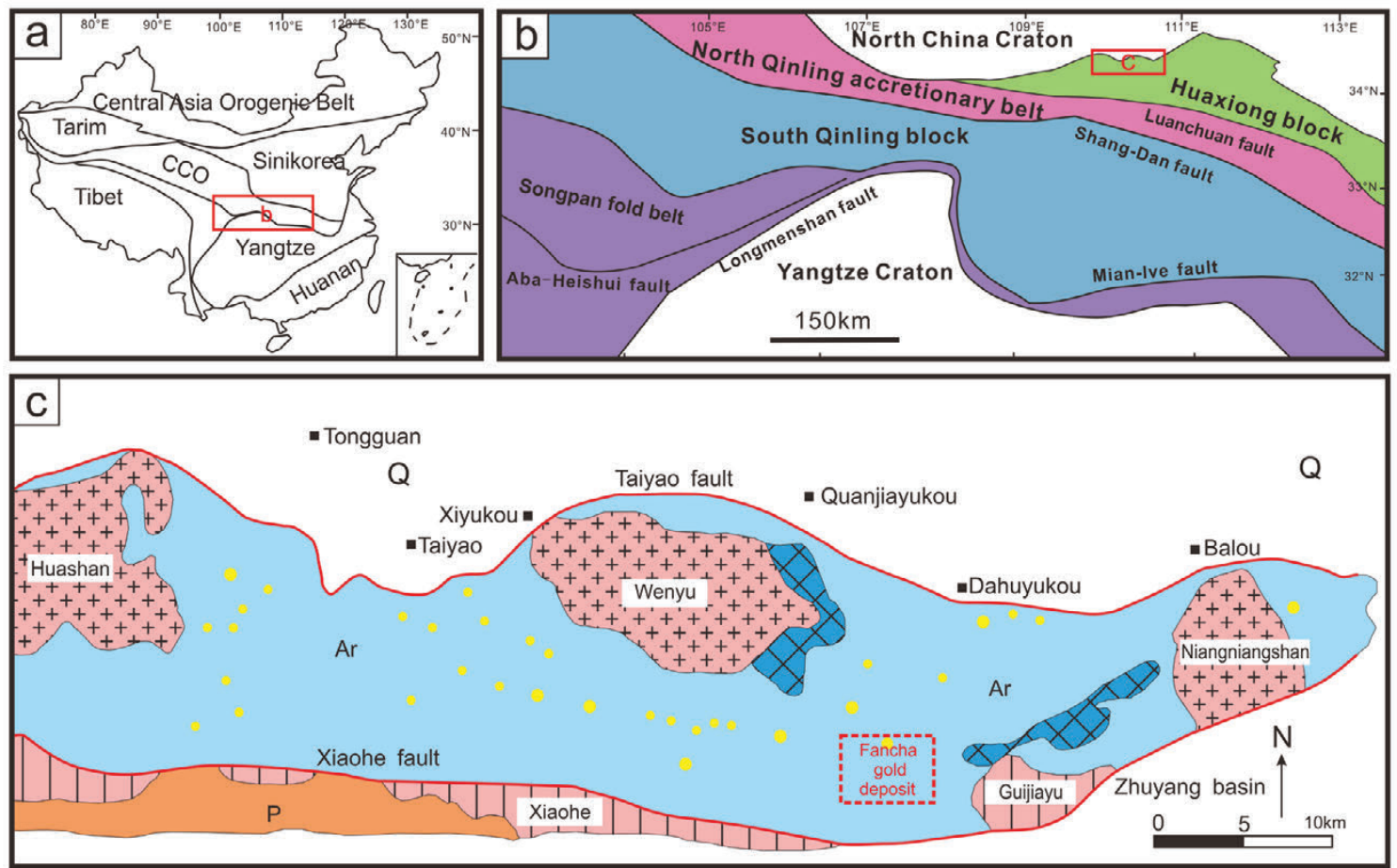

Q Quarternary

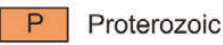

$\mathrm{Ar}$ New Archaean Taihua Group

Mesozoic granite

Precambrian granitoi Normal geological boundary fault

granite pegmatite

Au deposit

Research area

Figure 1. Map of the research area. a) Tectonic subdivisions of China (modified from LIU et al., 2015) CCO: Central China Orogen; b) tectonic subdivisions of the Qinling Orogen. (modified from ZHOU et al., 2015); c) geological map of the Xiaoqinling gold belt (modified from ZHOU et al., 2015).

investigating the geology, fluid inclusions and their stable isotope geochemistry. Furthermore, we explored the metallogenic mechanism by tracking the source of the ore-forming fluids and analyzing the fluid evolution.

\section{REGIONAL GEOLOGY}

The Xiaoqinling area is located at the northern margin of the eastern Qinling orogenic belt (MAO et al., 2010; WANG et al., 2008). The east side of this area begins in the Zhuyang basin in Henan and ends $50 \mathrm{~km}$ away in the west at Shanxi Huashan. The southern boundary is the Xiaohe fault, and to the north, the Taiyao fault. The area is 7 to $15 \mathrm{~km}$ wide, and overall it appears as an irregular strip (Fig. 1). The emergent stratum of this area is the Taihua Group (LUAN et al., 1990), which in accordance with other studies is divided into an upper and a lower basement. The upper basement is further sub-divided, from bottom to top, into the Guanyintang formation and the Huanchiyu formation (XU et al., 2009). The Guanyintang formation is dominated by biotiteplagiogneiss and plagioclase amphibole gneiss, while the Huanchiyu formation is composed of mainly marble and diopside marble. The lower basement comprises three units; from bottom to top they are the basic supracrustal rock, the Yangzhaiyu formation, and the Sifangou formation (FENG et al., 2014). The supracrustal rock is mainly composed of amphibolites and plagioclase amphibole gneiss, most of which is in the form of inclusions in metamorphic granite. The Yangzhaiyu formation is dominated by biotite-plagiogneiss and plagioclase amphibole gneiss while the Sifangou formation is mainly biotite plagiogneiss and biotite monzogneiss. In terms of construction and development, the region's major fold structures are the Wuli Village anticline, Qishuping syncline and the Laoyacha anticline (LUAN and
CHEN, 1990; MAO et al., 2005). The fault structures consist mainly of the approximately E-W trending axial folds, and the similarly trending E-W and nearly S-N trending faults. More than 500 ductile-brittle faults have been discovered in the area (HU et al., 2005; MAO et al., 2005), mostly trending E-W (ZHANG et al., 2009b). From the regional perspective, the E-W trending faults are the main ore-controlling structures. The south directed faults of the middle ore belt and the north directed faults of the northern ore belt are the main ore-controlling structures of large and medium-sized gold deposits in the region, striking several kilometres. Both the ductile shear zone and the brittle shear zone were found to contain gold-bearing quartz veins. The magmatic rocks in the area include Palaeoproterozoic granites, early Mesozoic granites and late Mesozoic granites (GAO et al., 2012; WANG et al., 2010). Among them, the palaeoproterozoic granites are mainly the Xiaohe and Guijiayu rock masses. From east to west, the Mesozoic granites contain the Niangniangshan, Wenyu and Huashan rock masses. In addition, most gold deposits in the region developed into Palaeoproterozoic and late Mesozoic mafic dykes, with the gold-bearing quartz veins existed as a symbiotic or mutual cross-cutting complex. The lithology is mainly diabase and lamprophyre, and the lamprophyre consisted of mainly camptonite and kersantite (NI, 1994; WANG et al., 2008; WANG et al., 2010).

\section{GEOLOGY}

The administrative division of the Fancha gold mining area belongs to Zhuyang Town, Lingbao City, Henan Province. The excavation strata in the mining area consist mainly of supracrustal rock $\left(\mathrm{Ar}_{3} B\right)$, the Yangzhaiyu $\left(\mathrm{Ar}_{3} y n\right)$, Sifangou $\left(\mathrm{Ar}_{3} s f\right)$, and Guanyintang formations $\left(\mathrm{Ar}_{3} g\right)$ in the Taihua group. Magmatic 

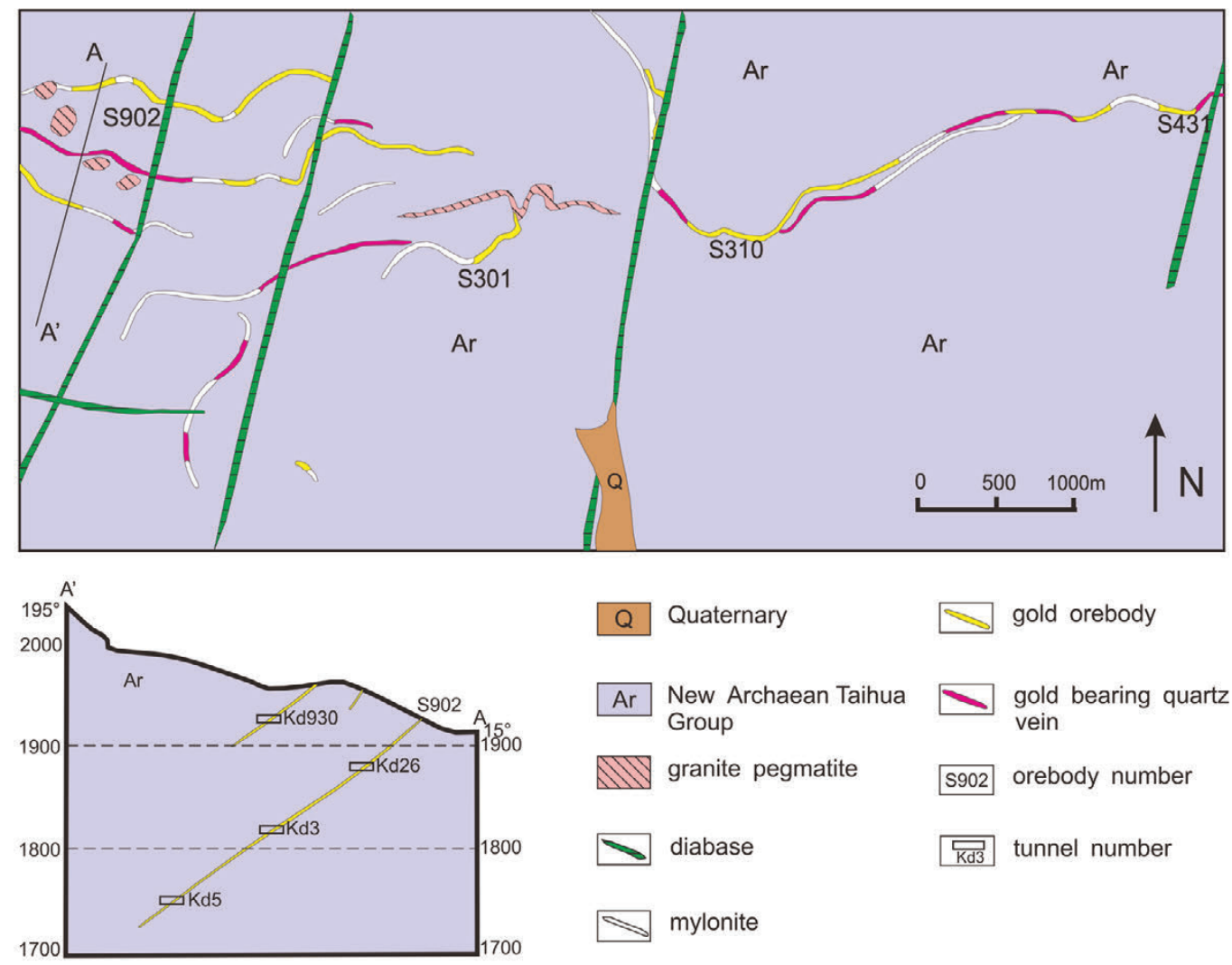

Quaternary

gold orebody

New Archaean Taihua Group

granite pegmatite

gold bearing quartz vein

diabase

\$902 orebody number

inge

mylonite

Figure 2. Geological sketch map of the Fancha gold deposit and geological cross section along the No.2 exploration line (modified from REN, 2012).

rocks exposed in the mining area include diabase porphyrite, monzonitic granite and granitic pegmatite (Fig. 2) (GAO et al., 2012; NI, 1994; WANG et al., 2008; WANG et al., 2010).

Diabase porphyrite is gray-green, with a blastoporphyritic texture, blocky structure and strong sericite alteration. It is widely distributed in the eastern mining area, mainly intruded in an approximately N-S orientation, and partially intruded as E-W trending veins.

Monzonitic granite is medium-fine grained, has a blocky structure, and is composed mainly of plagioclase, K-feldspar, quartz, biotite, a small amount of amphibole, and magnetite. It is distributed in the centre of the mining area.

Granitic pegmatite is grayish white, with a blocky structure. It is composed of microcline, plagioclase, quartz, and biotite and located in the southeast of the mining area.

The mining area mainly developed near E-W trending ductile-brittle faults. The faults are divided into compression-torsional and tensile faults, according to their mechanical properties. The compression-torsional faults are the ore-controlling structure, and the tensile faults have a destructive effect on the ore body. The mining area is located in the eastern tip of the Xiaoqinling anticline, and the anticline trends $\mathrm{E}-\mathrm{W}$ with a vertical axial plane (CHEN, 2013; REN, 2012).

\subsection{Characteristics of the ore body}

The Fancha gold deposit consists of four gold veins S902, S431, S310 and S301. This study is focused on the S902 vein (Fig. 2). The wall rocks of the $\$ 902$ vein are mainly composed of striped migmatite, Palaeoproterozoic granites and plagioclase amphibole gneiss of the Taihua group. The ore body is controlled by NNE brittle faults and its maximum depth is c. $710 \mathrm{~m}$. The ore body strikes $280^{\circ}$ in a SW direction, with an inclination angle of c. $40^{\circ}$, an average vein thickness of $0.50 \mathrm{~m}$, and a plate-like or evenly veined profile (REN, 2012).

\subsection{Ore Characteristics}

The ore minerals are pyrite, chalcopyrite, sphalerite, galena, and a small amount of natural gold. The ores are mainly quartz, Kfeldspar, sericite and carbonate. Paragenetic sequences of different ore stages with corresponding mineral assemblage are shown in Fig. 3i.

\subsubsection{The main ore minerals}

Pyrite is grayish yellow or light yellow and distributed throughout the entire mineralization process. Grain size varies greatly, mostly as fine particles but a small amount exhibits a visible cubic crystalline form. It often occurs as agglomerate with fine veins, or sparsely disseminated in quartz veins or mineralized altered rocks. In the early stage of mineralization, it is mostly a coarse pyrite euhedral-semi-shaped structure, with a disseminated or blocky structure in milky quartz (Fig. 3a,b). Cracks often occur at this stage, and the fissures can contain a small amount of gold (LU et al., 2013). During the main mineralization stage, the pyrite is mostly of medium-fine subhedral-allotriomorphic granular form, co-existing with the quartz and various metal sulfides (Fig. 3c,d). The pyrite appears as disseminated veinlets and lumps distributed on the side of the quartz vein or in the micro-cracks of the rock, usually with a higher gold content. At the late stage of mineralization, pyrite is generally fine subhedralallotriomorphic granular in form, distributed in carbonate veins or altered rocks and is associated with carbonate minerals such as calcite (Fig. 3e). The gold content is low. Gold content is generally 


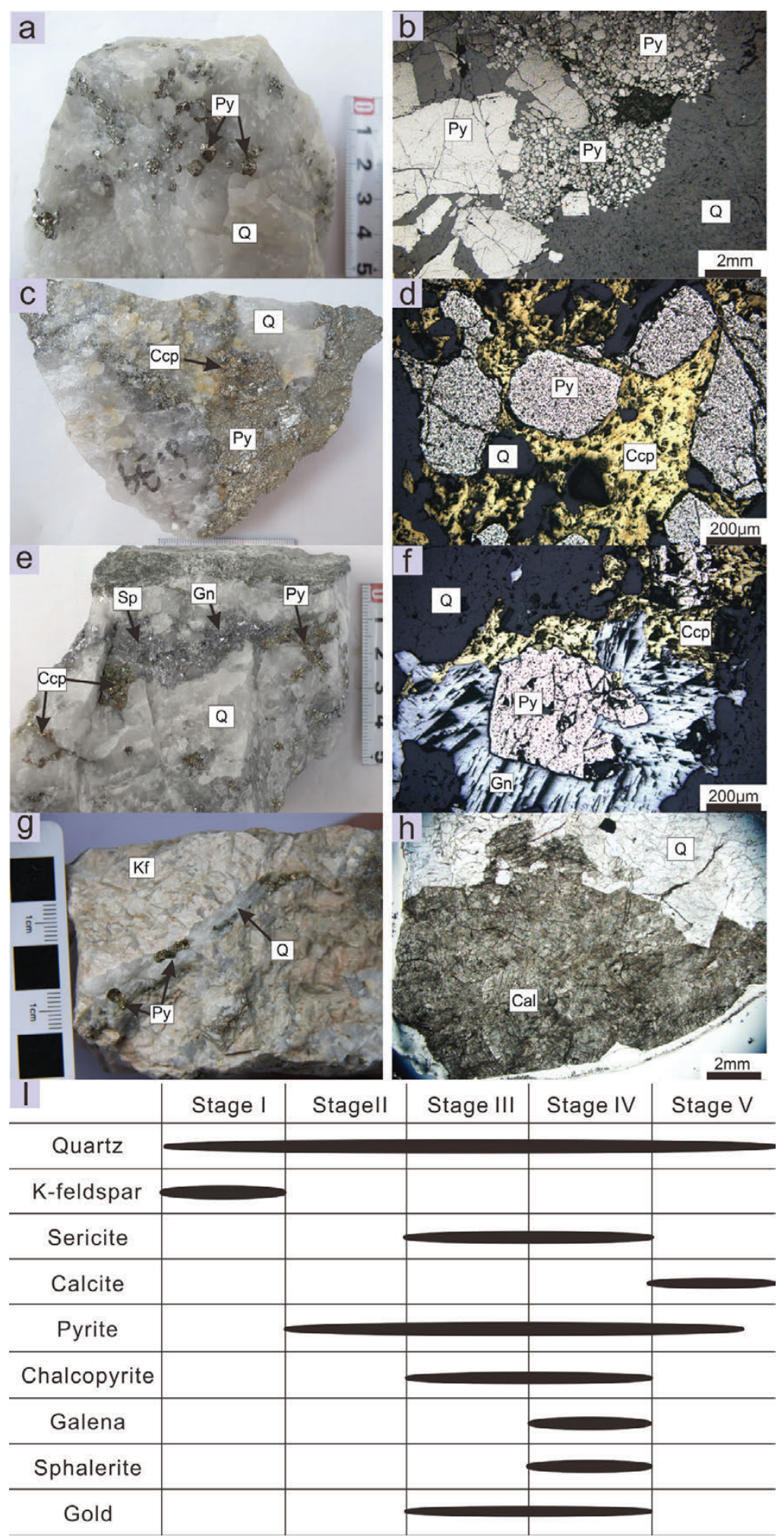

Figure 3. The main ore types and paragenetic sequences of different ore stages with corresponding mineral assemblages of the Fancha gold deposit. a) sparsely disseminated coarse pyrite in quartz; b) cataclastic coarse pyrite and fine-grained pyrite in quartz; c) fine-grained pyrite and chalcopyrite in smoky gray quartz; $d$ ) chalcopyrite encrusts fine-grained pyrite in quartz; e) veinlet pyrite + chalcopyrite + sphalerite + galena in quartz; f) quartz + pyrite + chalcopyrite + galena in quartz-polymetallic sulfide stage; $g$ ) potassium feldspar in early stage cut by quartz coarse-grained veins; $h$ ) quartz and calcite at the end of mineralization; i) paragenetic sequences of different ore stages with corresponding mineral assemblages. Q-quartz; Py-pyrite; Ccp-chalcopyrite; Sp-sphalerite; Cal-calcite; Gn-galena; Kf-K-feldspar.

positively correlated with the pyrite content in quartz veins or mineralized altered rocks.

Chalcopyrite is bright yellow, with a metallic lustre, and is fractured shell-like, and irregularly granular in shape (Figs. 3d,f). Usually it is found in quartz fine-grain pyrite and quartz polym- etallic sulfide stages. It forms as an agglomerate, disseminated or fine veins and is produced in quartz vein fissures or altered rocks, commonly associated with other sulfides.

Galena is mid gray with a metallic lustre, and occurs mainly in quartz veins. It is very unevenly distributed, with most at the 
polymetallic sulfide stage. It occurs in veinlets or as mass distribution with a euhedral-hypidiomorphic granular structure (Fig. 3e, f). A small amount is fine-grained. It is combined with pyrite, chalcopyrite, sphalerite and quartz as minerals, and is closely related to gold enrichment.

Sphalerite is bright silver gray, with a metallic lustre, medium-fine grained structure, and is mostly associated with the quartz polymetallic sulphide stage. It is mainly observed in association with galena and net veins, as agglomerations and is distributed in quartz veins (Fig. 3e).

\subsubsection{Main gangue minerals}

Quartz is the most important gangue mineral in the ore (usually $>90 \%$ ), and generally occurs in different-sized veins discontinuously distributed in the cracks. In the coarse-grained pyrite stage of mineralization, quartz is a milky white dense block assembly, often forming thick veins (Fig. 3a). During the fine pyrite phase, it is the colour of cigarette ash with a fine granular structure, often co-existing with pyrite and chalcopyrite (Fig. 3c). It is mainly distributed in fine vein quartz at micro-cracks in the veins and is slightly more transparent during this phase. At the polymetallic sulphide stage, quartz is generally colourless, transparent, translucent, and euhedral or subhedral, co-existing with polymetallic sulphides (Fig.3e). It is distributed in the early stage quartz veins. At the carbonate stage, the quartz is white and granular and associated with calcite (dolomite) and pyrite. The fine veins or small clumps are scattered at the edges of, or in the altered rocks of the veins (Fig. 3g).

K-feldspar is pink and belongs to a group of potash altered minerals. It is generally distributed in the form of aggregates, which are produced in large veins or dip-like forms, and often co-exists with quartz. The type of K-feldspar is microcline, and polysynthetic twins and crosshatched twins are visible under the microscope (Fig. 3g).

Sericite forms microscopic scaly aggregates with directional alignment, complete cleavage and a silky lustre. It is closely related to gold mineralization.

Carbonate is mainly calcite and it is colourless, transparent or translucent, with complete cleavage in both directions and a low degree of crystallization. It forms as irregular veins (Fig. 3h) among other surrounding rocks with carbonate minerals and very low levels of mineralization.

Through detailed ocular and microscopic observation, it can be concluded that the Fancha gold ore includes the following structures: euhedral or subhedral-granular, allotriomorphic granular including, cataclastic and filling structure with a metasomatic texture. The Fancha gold is mainly a vein-like, disseminated, and agglomerate structure.

\subsection{Wall rock alteration}

The common surrounding rock alterations in the mining area include silicification, beresitization, potash feldspathization, chloritization, epidotization and carbonation. Rock alteration in the area is not strong, and all kinds of alterations are distributed at the boundary of the contact zone between the gold-bearing quartz vein and wall rocks, showing characteristics of linear alteration. Silicide is the most widely developed alteration in the Fancha gold deposit, and it is disseminated in wall rocks within the fault zone as lumps and mesh-vein by metasomatism and infilling. The hydrothermal fluid is relatively well developed in the early and middle stages, and rare in the later stage. The lithology of beresitization is accompanied by mineralization, and densely disseminated as lumps and fine veins. It is particularly well developed in the early and middle stages of hydrothermal alteration and is closely associated with mineralization. Potash feldspathization often occurs in the early stage of mineralization, is spread in the distal rocks in disseminated or veined forms, and is occasionally observed in the adjacent wall rock. Chloritization and epidotization is evidenced by a pale green colour and is distributed in the wall rock in clumped and disseminated forms, and is not closely related to mineralization. Carbonation is formed in the late stage of mineralization with mainly fine veins, usually of quartz carbonate. The main minerals are calcite, dolomite and ferro-dolomite.

\subsection{Metallogenic stage}

Based on comprehensive field and laboratory study, the Fancha gold deposit mineralization process can be divided into five stages recognised by different mineral assemblages (Fig. 4).

Quartz-K-feldspar stage (I): early potassium-rich fluid migrated along the fractured zones and reacted (water-rock) with the roof and floor of the wall rocks, forming a strong planar massive potassic alteration. This stage is the preparatory stage of mineralization.

Quartz coarse pyrite stage (II): ore-bearing hydrothermal fluids filled fractures of the wall rock appearing as large milky quartz veins and the ore is a coarse-grained pyrite type. The pyrite is bright yellow, and generally occurs as medium-coarse cubes or pentagonal dodecahedron with a good degree of euhedral form.

Quartz fine-grain pyrite stage (III): this stage is the main mineralization stage. The ore-forming hydrothermal fluids penetrate into the large quartz vein fractures of the early stage as fine veins, characterized by fine-grained pyrite and smoky quartz. It is accompanied by a small amount of allotriomorphic chalcopyrite deposition.

Quartz-polymetallic sulfide stage (IV): the ore-bearing hydrothermal fluids continue to fill the quartz vein fractures and are enriched in the local area by metasomatism. Sulphide ores disseminated by veinlets are typically present in this stage. The main metallic mineral assemblage is pyrite, chalcopyrite, galena, sphalerite and gold. The gangue minerals are smoky quartz, with a granular texture. A small amount of sericite is developed in the fractures.

Quartz carbonate stage (V): the last stage of mineralization with no gold mineralization. The plagioclase amphibole gneiss is mainly filled with carbonate veins (calcite, dolomite), and in open space, the carbonate mineral precipitated as crystal clusters with the quartz.

\section{Fluid characteristics}

\subsection{Samples and analytical methods}

All the samples were collected from the S902 vein in the Fancha gold deposit. Based on the different mineralization stages, we collected 5 samples at each stage for further study (Table 1). The samples were processed by the Hebei Institute of Geology and Mineral Resources Survey laboratory into 10 inclusion sections.

Micro thermometric measurements were performed using a LinkamMDSG600 heating-freezing stage attached to a Leitz Ortholux transmitted light microscope connected to a television camera and screen. The stage was calibrated using synthetic fluid inclusions. The estimated accuracy was $\pm 0.1^{\circ} \mathrm{C}$ at temperatures below $30{ }^{\circ} \mathrm{C}$ and $\pm 1{ }^{\circ} \mathrm{C}$ at temperatures above $30^{\circ} \mathrm{C}$. The warm- 
if ing rate was maintained at 0.2 to $5{ }^{\circ} \mathrm{C}$ per minute, and the heating rate was reduced to $0.2^{\circ} \mathrm{C}$ per minute when close to phase-change conditions. Freezing experiments were performed first on all sections to avoid inclusion decrepitation. The measured phase transitions included the melting temperature of ice (Tm-ice), the melting temperature of solid $\mathrm{CO}_{2}\left(\mathrm{~T}_{\mathrm{m}-\mathrm{CO}_{2}}\right)$, the temperature of $\mathrm{CO}_{2}$-clathrate dissociation $\left(\mathrm{T}_{\mathrm{m}-\mathrm{cl}}\right)$, the homogenization tempera- ture of $\mathrm{CO}_{2}\left(\mathrm{~T}_{\mathrm{h}-\mathrm{CO}_{2}}\right)$, and the total homogenization temperature (Th). Salinities were calculated using the equations of BODNAR (1993) for aqueous fluids and COLLINS (1979) for aqueous-carbonic fluids.

Six samples were collected for each metallogenic stage. As we failed to collect suitable carbonate samples at the carbonate stage and it is not the main research focus, we did not investigate
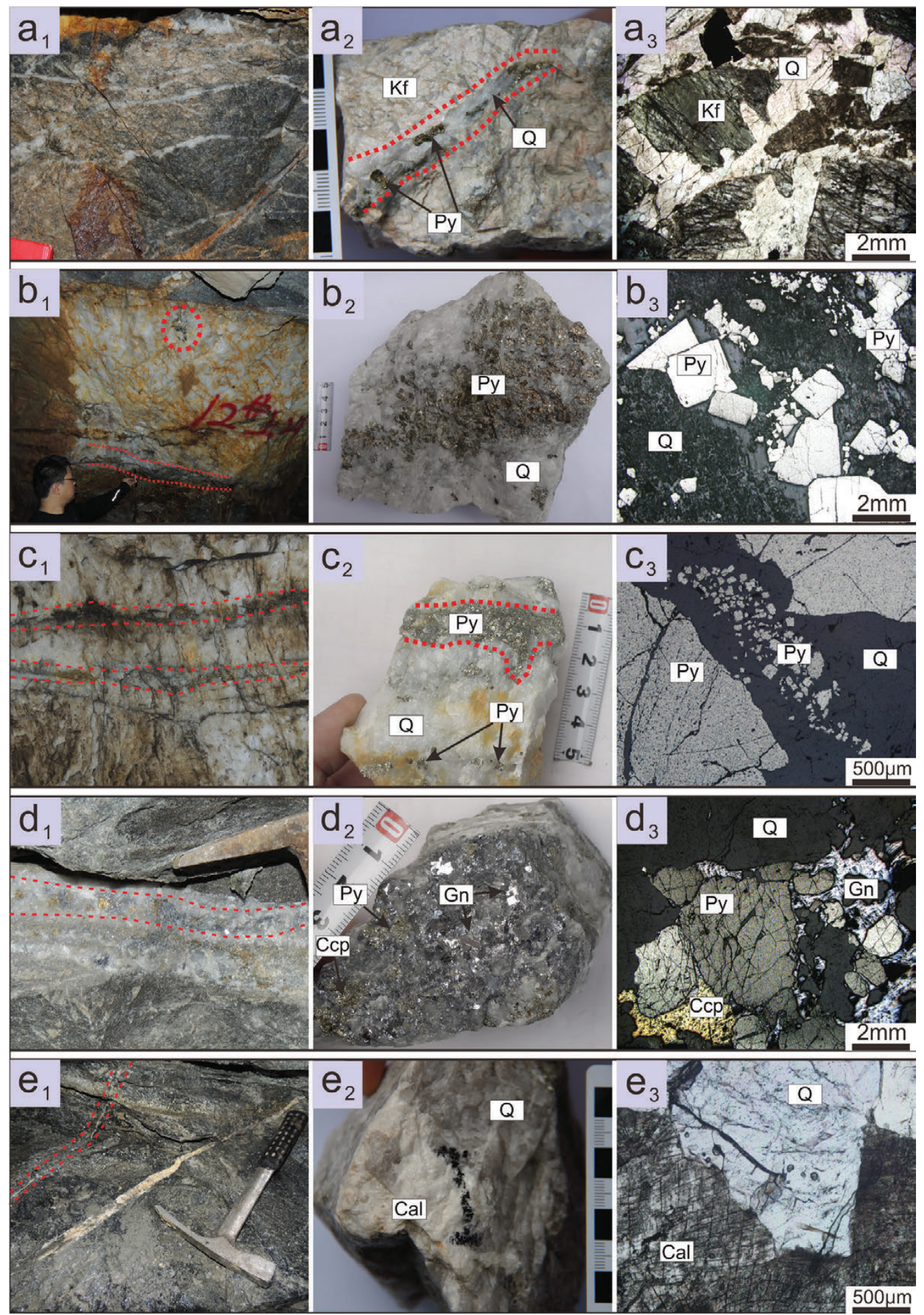

Figure 4. Characteristics of the different types of mineralization of the Fancha gold deposit. $a_{1}$ ) - $a_{3}$ ) Photographs of stage $\mathrm{l}_{1}$ potassium feldspar vein cut by quartz coarse-grained pyrite vein in hand specimen; $\left.b_{1}\right)$ - $b_{3}$ ) Photographs of stage II, massive or sparsely disseminated coarse pyrite in milky white quartz, and the completely filled fractures of the wall rock as veins; $c_{1}$ ) - $c_{3}$ ) Photographs of stage III, smoky gray quartz fine-grained pyrite veins of stage III are filled in milky white quartz fractures of stage II; $\left.d_{1}\right)-d_{3}$ ) Photographs of stage IV, polymetallic sulfide veins fill in the fractures of milky white quartz; $e_{1}$ ) - $e_{3}$ ) Photographs of stage $V$, polymetallic sulfide veins cut by carbonate veins. Q-quartz; Kf-K-feldspar; Py-pyrite; Ccp- chalcopyrite; Gn- galena; Cal-calcite. 


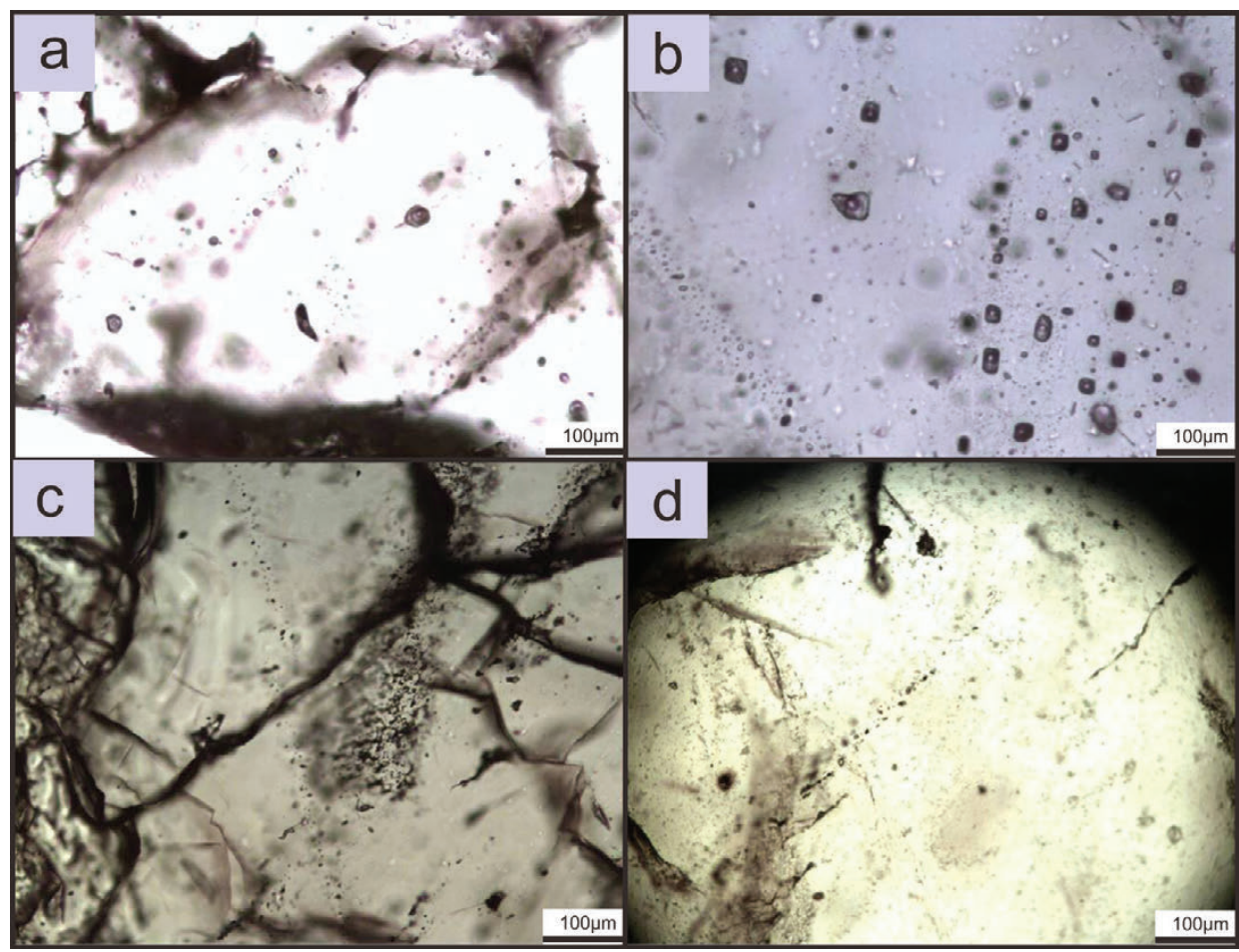

Figure 5. Genetic types of fluid inclusions in the Fancha deposit. a) isolated primary inclusions in single quartz; b) a group of primary inclusions distributed along the growth zoning of quartz; c) linear secondary inclusions traverse crystals; d) linear secondary inclusions along cracks of crystal.

it further. The oxygen and hydrogen isotopes were analyzed on a Finnigan MAT253 mass spectrometer in the Analytical Laboratory, Beijing Research Institute of Uranium Geology, using the methods outlined by DING (1980). Oxygen gas was generated from the samples by a quantitative reaction with $\mathrm{BrF}_{5}$ in externally heated nickel vessels. Hydrogen in the extracted water from the fluid inclusions within the quartz separates was replaced by zinc at c. $600{ }^{\circ} \mathrm{C}$ and released for mass spectrometry. The isotope data are reported in ppm relative to the Vienna SMOW standard for oxygen and hydrogen. Total uncertainties were estimated to be better than $\pm 0.2 \%$ for $\delta^{18} \mathrm{O}$ and $\pm 1 \%$ for $\delta \mathrm{D}$. The oxygen isotope ratios of water in equilibrium with the minerals are calculated using the fractionation formula reported by CLAYTON et al. (1972).

\subsection{Types of fluid inclusions}

\subsubsection{Genetic types}

Based on their genesis, fluid inclusions of the Fancha gold deposit are classified as primary, secondary and pseudo secondary inclusions (LU, 2004). Isolated primary inclusions of suborbicular or oval shape with a diameter of $5 \sim 40 \mu \mathrm{m}$ often have a discrete distribution (Fig. 5a) and are occasionally observed along the growth zoning of quartz (Fig. 5b). Linear secondary inclusions are often distributed in micro-cracks cutting through the boundary of quartz crystals, with a elongate but irregular in shape and irregular shape (Fig. 5c, d). However, since they cannot represent ore fluid, they are not discussed further. Pseudo secondary inclusions, with compositions consistent with the primary inclusions, are elongate and formed as linear groups distributed within quartz micro-cracks during crystal growth and represent the oreforming fluids.

\subsubsection{Phase types}

Petrographic observations indicated that the fluid inclusions of the Fancha gold deposit have 3 main phases: three-phase $\mathrm{CO}_{2}$ - bearing inclusions $\left(\mathrm{V}_{\mathrm{CO}_{2}}+\mathrm{L}_{\mathrm{CO}_{2}}+\mathrm{L}_{\mathrm{H}_{2} \mathrm{O}}, \mathrm{L}_{\mathrm{H}_{2} \mathrm{O}}>50 \%\right)$, threephase $\mathrm{CO}_{2}$-rich inclusions $\left(\mathrm{V}_{\mathrm{CO}_{2}}+\mathrm{L}_{\mathrm{CO}_{2}}+\mathrm{L}_{\mathrm{H}_{2} \mathrm{O}}, \mathrm{L}_{\mathrm{H}_{2} \mathrm{O}}<50 \%\right)$ and two-phase aqueous inclusions $\left(\mathrm{L}_{\mathrm{H}_{2}} \mathrm{O}+\mathrm{V}_{\mathrm{H}_{2} \mathrm{O}}\right)$. Occasionally there are also vapour inclusions $\left(\mathrm{V}_{\mathrm{CO}_{2}}\right.$ or $\left.\mathrm{V}_{\mathrm{H}_{2} \mathrm{O}}\right)$ and liquid inclusions $\left(\mathrm{L}_{\mathrm{CO}_{2}}\right.$ or $\left.\mathrm{L}_{\mathrm{H}_{2}} \mathrm{O}\right)$.

Three-phase $\mathrm{CO}_{2}$-bearing inclusions consisted of brine solution, $\mathrm{V}_{\mathrm{CO}_{2}}$ and $\mathrm{L}_{\mathrm{CO}_{2}}$. These inclusions are widely distributed throughout the entire process of mineralization, representing the main inclusion type of the Fancha gold deposit. The $\mathrm{V}_{\mathrm{CO}_{2}}+\mathrm{L}_{\mathrm{CO}_{2}}$ phase accounts for about 15 - 50\% of the inclusion volume, and the ratio of $\mathrm{V}_{\mathrm{CO}_{2}}$ and $\mathrm{L}_{\mathrm{CO}_{2}}$ is approximately 5 - 35\%. Such inclusions are often suborbicular, irregularly-shaped, or negative crystalline with a diameter of 10 to $40 \mu \mathrm{m}$ (Fig. $6 \mathrm{a}_{1}-\mathrm{a}_{3}$ ).

Three-phase $\mathrm{CO}_{2}$-rich inclusions consisted of brine solution, $\mathrm{V}_{\mathrm{CO}_{2}}$ and $\mathrm{L}_{\mathrm{CO}_{2}}$. These inclusions are mainly found in the polymetallic sulfide stage, and rarely in other mineralization stages. The volume of $\mathrm{V}_{\mathrm{CO}_{2}}+\mathrm{L}_{\mathrm{CO}_{2}}$ accounts for c. $50-80 \%$ of the total volume. The ratios of $\mathrm{V}_{\mathrm{CO}_{2}}$ and $\mathrm{L}_{\mathrm{CO}_{2}}$ are approximately $5-15 \%$. Inclusions often are suborbicular or oval, and columnar crystalline or negative crystalline. Compared with the size of the threephase $\mathrm{CO}_{2}$-bearing inclusions, they have a slightly smaller diameter of usually $5-25 \mu \mathrm{m}$ (Fig. $6 \mathrm{~b}_{1}-\mathrm{b}_{3}$ ).

Two-phase aqueous inclusions are comprised of $\mathrm{L}_{\mathrm{H}_{2} \mathrm{O}}$ and $\mathrm{V}_{\mathrm{H}_{2} \mathrm{O}}$. The vapour-liquid ratio is less than $15 \%$, and they are often elongated and suborbicular, with a diameter mostly less than $20 \mu \mathrm{m}$ (Fig. $\left.6 \mathrm{c}_{1}-\mathrm{C}_{2}\right)$.

Vapour inclusions develop in all stages, showing vapourphase at room temperature with no liquid and no significant change with increasing and decreasing temperature. They are dark black, mostly suborbicular, short cylindrical and regular

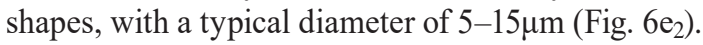

Liquid inclusions at room temperature, are only a single liquid phase $\left(\mathrm{L}_{\mathrm{H}_{2} \mathrm{O}}\right)$ with no vapour phase and do not change with changes in temperature. There are only a few of this type of in- 
clusion, they are colourless, transparent and filled with aqueous solution. The general size is $5-10 \mu \mathrm{m}$, mainly formed in the late stages of mineralization (Fig. $6 \mathrm{e}_{1}, \mathrm{e}_{3}$ ).

In addition, microscopic observation showed that daughter mineral-bearing inclusions are found in the polymetallic sulphide stage (Fig. 6d). However, due to their rarity, they were ignored. There are a few pure $\mathrm{L}_{\mathrm{CO}_{2}}$ inclusions, mainly found in the metallogenic stage. $\mathrm{V}_{\mathrm{CO}_{2}}$ occurs during cooling to below $20^{\circ} \mathrm{C}$. The possible mechanism is that the original homogeneous fluid is subjected to structural decompression or mixed with meteoric water to cause fluid boiling, so a large amount of vapour escapes and the mineral captures the inclusion. There are many "bottle-neck" shapes in the sample, probably because these inclusions have been subjected to local stress effects associated with the primary mineral after crystallization. It is noteworthy that different types (or one type with various ratios of phases) of inclusions are present in the field during the main mineralization stage, suggesting the possibility of fluid immiscibility with the ore-forming fluid (LU, 2004; ROEDDER, 1984).

\subsection{Fluid inclusion assemblage}

The concept of the fluid inclusion assemblage (FIA) was proposed by TOURET (2001) and GOLDSTEIN (2001). FIA represents a set of the representative period inclusions captured in a certain stage. All inclusions of a FIA have similar features and they should have a substantially similar homogenization temperature (the difference does not exceed $15^{\circ} \mathrm{C}$ ). However, due to frequent tectonic activity in the Xiaoqinling area, the mineralization and geological complexity means that the same FIA inclusions have a slight temperature variation. The reason for this is that after being captured, the inclusions suffered varying degrees of destruction and transformation (stretching or partially open), with stretching typically resulting in a high temperature (CHI et al., 2008). Therefore, if the temperature difference of the inclusions in one FIA is within a $20-25^{\circ} \mathrm{C}$ range, it is still considered that the inclusion thermometry data are valid. Robust data was not obtained for potash feldspathization (stage I) so it was excluded from further study. The distribution of inclusions and the inclusion characteristics of each mineralization stage are shown in Fig. 7.

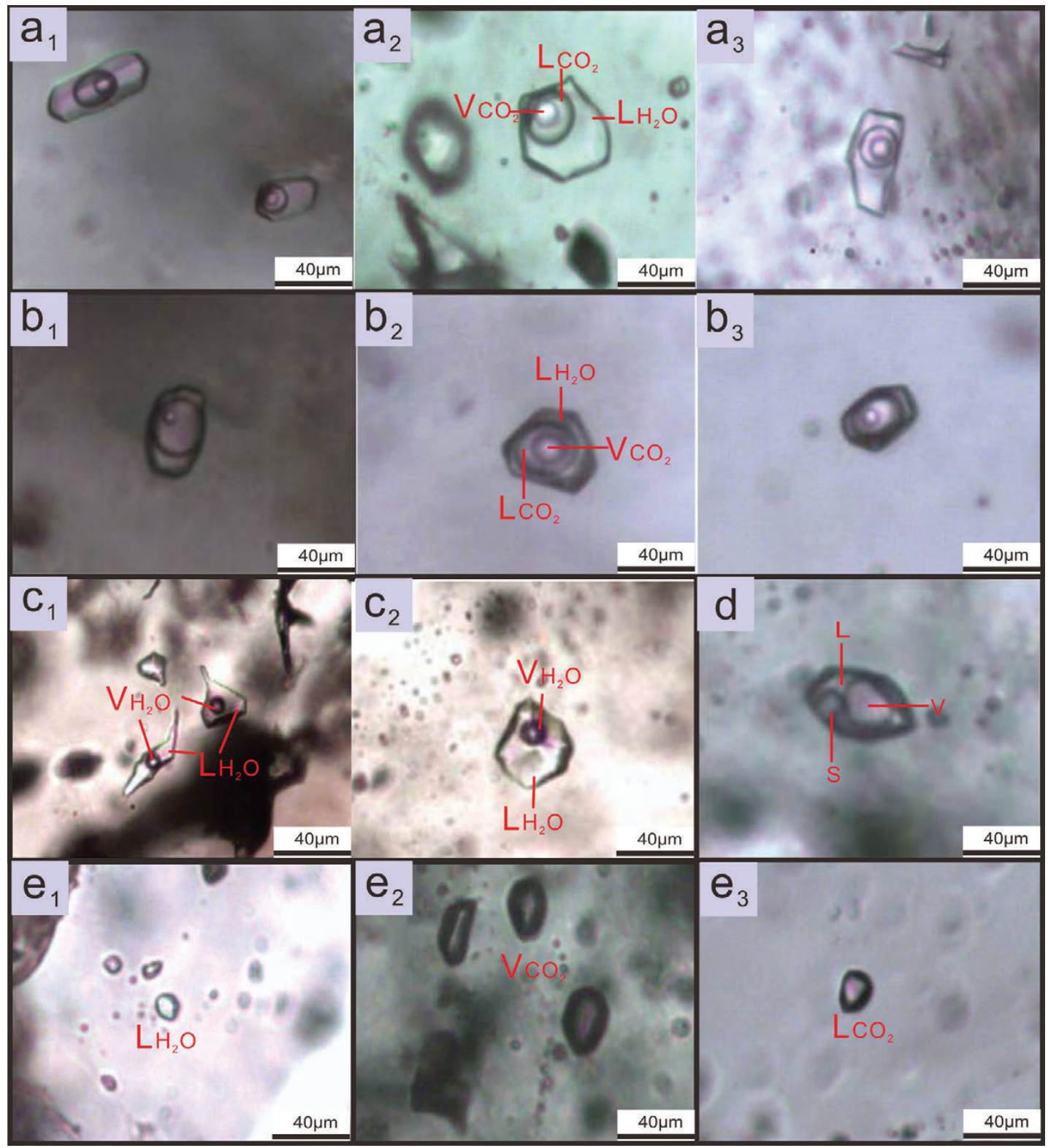

Figure 6. Phase types of fluid inclusions in the Fancha deposit. $\left.a_{1}\right)$ - $\left.a_{2}\right)$ three-phase $\left(\mathrm{O}_{2}\right.$-bearing inclusions; $\left.b_{1}\right)$ - $\left.b_{3}\right)$ three-phase $\left(\mathrm{CO}_{2}\right.$-rich inclusions; $\left.c_{1}\right)$ - $\left.c_{2}\right)$ twophase aqueous inclusions; $d$ ) three-phase daughter mineral-bearing inclusion; $\left.\mathrm{e}_{1}\right)$ aqueous inclusion; $\left.\mathrm{e}_{2}\right)$ vapour inclusions $\left.\left(\mathrm{CO}_{2}\right) ; \mathrm{e}_{3}\right)$ liquid inclusion $\left(\mathrm{CO}_{2}\right)$. 


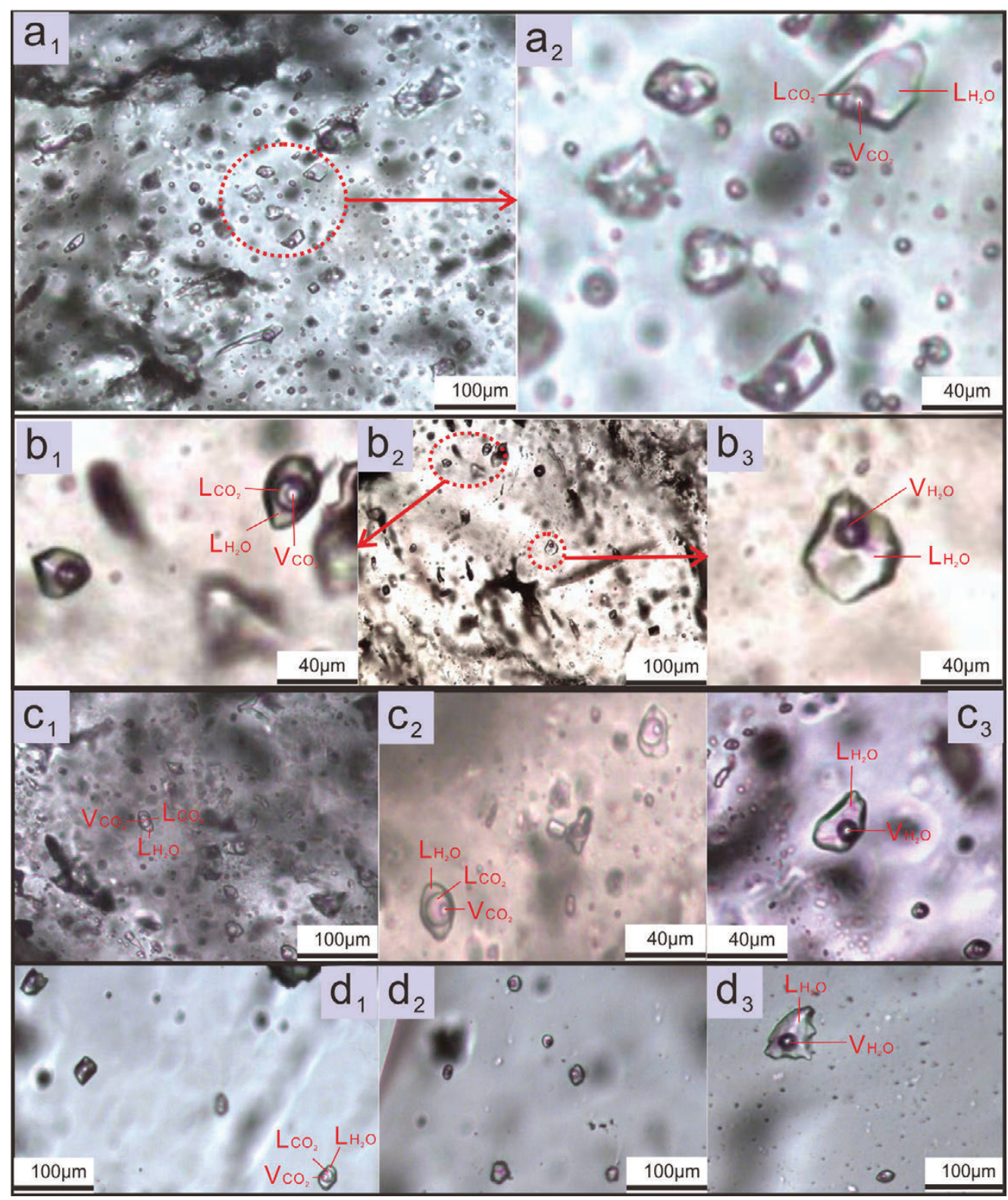

Figure 7. Characteristics of FIA in quartz in different stages of mineralization. $\left.a_{1}\right)$ - $\left.a_{2}\right)$ three- phase $\mathrm{CO}_{2}$-bearing and three-phase $\mathrm{CO}_{2}$-rich inclusions in stage $I I$; $\left.b_{1}\right)$ $-b_{3}$ ) three-phase $\mathrm{CO}_{2}$-bearing inclusions, three-phase $\mathrm{CO}_{2}$-rich and two-phase aqueous inclusions in stage $\left.\mathrm{Ill} ; \mathrm{c}_{1}\right)$ - $\left.\mathrm{c}_{3}\right)$ three-phase $\mathrm{CO}_{2}$-rich inclusions and two-phase aqueous inclusions in stage $\left.\mathrm{IV} ; \mathrm{d}_{1}\right)-\mathrm{d}_{3}$ ) two- phase aqueous, three-phase $\mathrm{CO}_{2}$-rich and three phase $\mathrm{CO}_{2}$-bearing inclusions in stage $\mathrm{V}$.

Quartz coarse-pyrite stage (II): the main inclusions are three-phase $\mathrm{CO}_{2}$-bearing inclusions, accounting for c. 70 percent of the total number of inclusions. Inclusions are distributed as large strips and large planar forms, as well as visible strips and linear discrete shapes. Their abundance can reach $80 \%$, they have a large volume, and range from 15 to $40 \mu \mathrm{m}$ in diameter. They are usually negatively crystalline, suborbicular, nearly elliptical and elliptical. The filling degree generally varies from $50 \%$ to $80 \%$ (Fig. $7 \mathrm{a}_{1}-\mathrm{a}_{2}$ ). A few three-phase $\mathrm{CO}_{2}$-rich inclusions were also discovered.

Quartz fine-grain pyrite stage (III): mainly composed of three-phase $\mathrm{CO}_{2}$-bearing inclusions $(60 \%)$, some three-phase $\mathrm{CO}_{2}$-rich inclusions (30\%) and a few two-phase aqueous inclusions $(10 \%)\left(\right.$ Fig. $\left.7 \mathrm{~b}_{1}-\mathrm{b}_{3}\right)$. Primary inclusions are distributed in discrete isolates, partially banded and occurring in groups. Inclusion size is smaller than at stage (II), $10-25 \mu \mathrm{m}$ in diameter. Shape morphology is suborbicular, elliptical or irregular. The fill degree is $40 \%$ to $60 \%$.
Polymetallic sulphide stage (IV): three-phase mainly $\mathrm{CO}_{2}$ rich inclusions (95\%), two-phase liquid-rich inclusions (5\%), very small amounts of pure liquid phase $\left(\mathrm{L}_{\mathrm{CO}_{2}}\right)$ inclusions, and occasionally some three-phase daughter mineral-bearing inclusions (Fig. $7 \mathrm{C}_{1}-\mathrm{C}_{3}$ ). The inclusions are disordered, distributed in groups, and mostly a primary isolated shape. The abundance of the inclusions decreased slightly in comparison with the earlier stages, and the primary inclusions were negative crystalline, and suborbicular, or elliptical. Inclusion diameter is $5-20 \mu \mathrm{m}$, with generally less than $50 \%$ infill.

Carbonate stage (V): mainly two-phase liquid-rich inclusions (40\%), three-phase $\mathrm{CO}_{2}$-bearing inclusions (35\%) and a few three-phase $\mathrm{CO}_{2}$-rich inclusions. The inclusions are sparse, disordered and discretely distributed. Occasionally, small-area clusters are distributed in a strip. The number of inclusions is small, and nearly circular, elliptical, negative crystal, pointed, or a regular shape. The inclusion volume is small, with a diameter generally from $5-10 \mu \mathrm{m}$. The fill degree is $20 \%-80 \%\left(\right.$ Fig. $\left.7 \mathrm{~d}_{1}-\mathrm{d}_{3}\right)$. 
Table 1. Characteristics of fluid inclusion samples in different stages.

\begin{tabular}{cccccc}
\hline Sample & Stage & Host mineral & Description & Location \\
\hline FX013 & I & Quartz & Quartz coarse-grained pyrite fine vein cutting K-feldspar & Adit1100 \\
FX037 & II & Quartz & Quartz coarse-grained pyrite veins in wall rocks & $3 W 10$, Adit1050 \\
FX016 & III & Quartz & Smoky quartz vein with fine-grained pyrite filling in the fractures of milky quartz & $6 \mathrm{E} 18$, Adit1020 \\
FX028 & IV & Quartz & Fine-grained densely disseminated polymetallic sulphide ore & W9, Adit1050 \\
FX038 & V & Quartz & A small amount of calcite on the quartz in the late stage & $6 \mathrm{E} 16$, Adit1020 \\
\hline
\end{tabular}

Table 2. Summary of microthermometric data on fluid inclusions in the Fancha gold deposit.

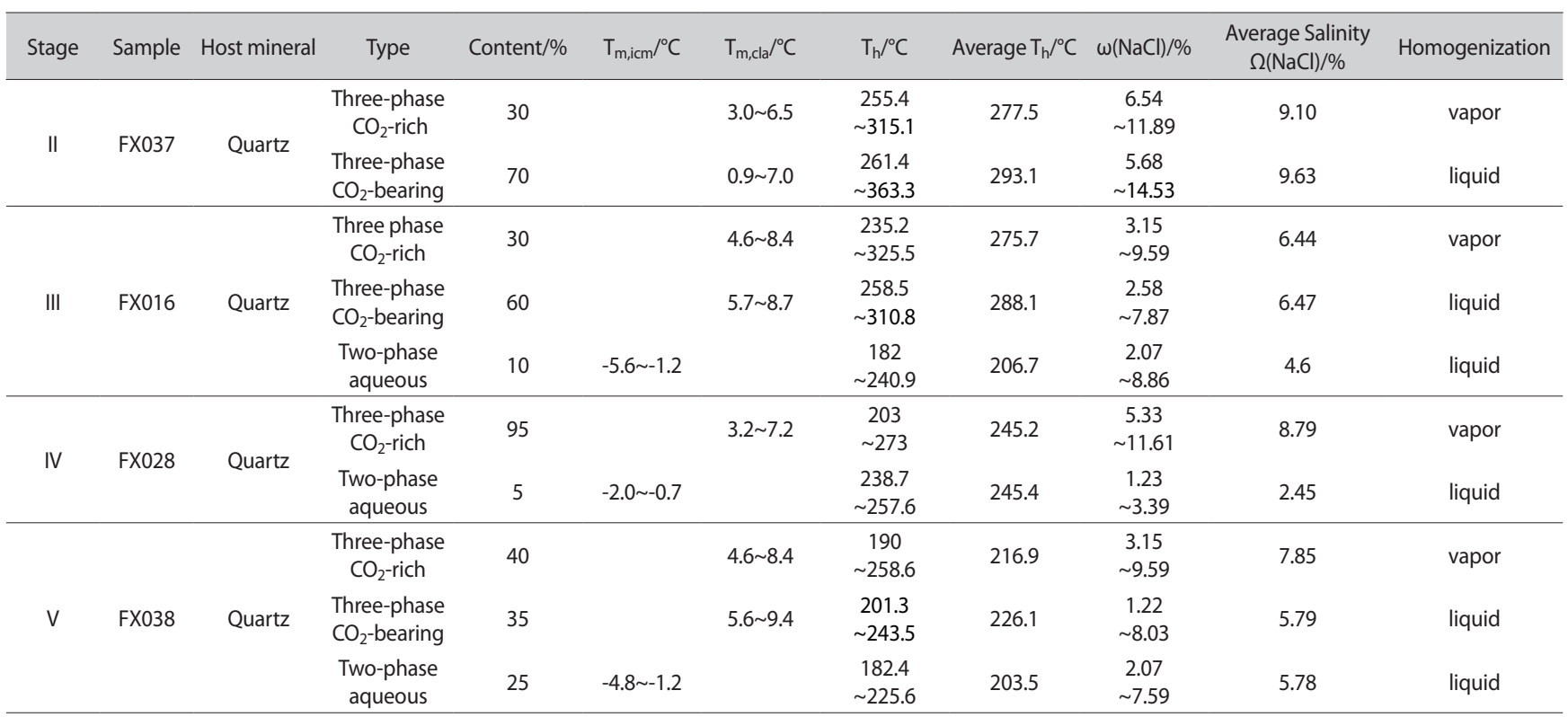

\subsection{Homogenization temperature, salinity and density}

The microscopic temperature measurement data of fluid inclusions in each metallogenic stage in the Fancha gold deposit can be described as follows (Table 2).

Quartz coarse-pyrite stage (II): the homogenization temperature of three-phase $\mathrm{CO}_{2}$-rich inclusions is $255.4-315.1^{\circ} \mathrm{C}$, with a mean of $277.5^{\circ} \mathrm{C}$, equalizing to a homogeneous vapour phase. The homogenization temperature of three-phase $\mathrm{CO}_{2}$ bearing inclusions is $261.4-363.3{ }^{\circ} \mathrm{C}$, with a mean of $293.1^{\circ} \mathrm{C}$, equalizing to a homogeneous liquid phase. The melting temperature of the solid-phase $\mathrm{CO}_{2}$ is $-60.0--56.7^{\circ} \mathrm{C}$, which is below the melting temperature of pure $\mathrm{CO}_{2}$ in the solid phase $\left(-56.6^{\circ} \mathrm{C}\right)$. This indicates that in addition to $\mathrm{CO}_{2}$ inclusions, the vapour may also contain other ingredients (e.g., $\mathrm{CH}_{4}$ ). The melting temperature of $\mathrm{CO}_{2}$ clathrate in the three-phase $\mathrm{CO}_{2}$-rich inclusion is $3.0-6.5^{\circ} \mathrm{C}$. The salinity was determined from a temperature salinity table for $\mathrm{CO}_{2}$ clathrate melting (COLLINS, 1979). The salinity is $6.54-11.89$ wt\% $\mathrm{NaCl}$ equiv., with an average of 9.24 wt $\% \mathrm{NaCl}$ equiv. The $\mathrm{CO}_{2}$ clathrates of three- phase $\mathrm{CO}_{2}$ bearing inclusion has a melting temperature of 0.9 to $7.0^{\circ} \mathrm{C}$. The salinity varies from 5.68 to $14.53 \mathrm{wt} \% \mathrm{NaCl}$ equiv., with an average of $9.63 \mathrm{wt} \% \mathrm{NaCl}$ equiv. The homogenization temperature of the $\mathrm{CO}_{2}$ part is $25.0-31.0^{\circ} \mathrm{C}$. According to the known relationship between the homogenization temperature of each part and the $\mathrm{CO}_{2}$ phase density, the relative density of the $\mathrm{CO}_{2}$ phase was calculated as c. $0.70-0.80 \mathrm{~g} / \mathrm{cm}^{3}$.

Quartz fine-pyrite phase (III): the homogenization temperature of three-phase $\mathrm{CO}_{2}$-rich inclusions is $235.2-325.5^{\circ} \mathrm{C}$, with a mean of $275.7^{\circ} \mathrm{C}$, equalizing to a homogeneous vapour phase. The homogenization temperature of three-phase $\mathrm{CO}_{2}$ bearing inclusions is $258.5-310.3^{\circ} \mathrm{C}$, with an average of $288.1^{\circ} \mathrm{C}$, equalizing to a homogeneous liquid phase. The melting temperature of the solid-phase $\mathrm{CO}_{2}$ is $-60.0-56.7^{\circ} \mathrm{C}$, which is below the melting temperature of pure $\mathrm{CO}_{2}$ in the solid phase $\left(-56.6{ }^{\circ} \mathrm{C}\right)$. For $\mathrm{CO}_{2}$ clathrate of three-phase $\mathrm{CO}_{2}$-rich inclusion, the melting temperature is $4.6-8.4^{\circ} \mathrm{C}$. Salinity is $3.15-9.59 \mathrm{wt} \% \mathrm{NaCl}$ equiv., with an average of $6.44 \mathrm{wt} \% \mathrm{NaCl}$ equiv. The $\mathrm{CO}_{2}$ clathrates of three-phase $\mathrm{CO}_{2}$ bearing inclusion has a melting temperature of 5.7 to $8.7^{\circ} \mathrm{C}$. The salinity is from 2.58 to $7.87 \mathrm{wt} \% \mathrm{NaCl}$ equiv., (average $6.47 \mathrm{wt} \% \mathrm{NaCl}$ equiv.). The homogenization temperature of the $\mathrm{CO}_{2}$ part is $13.6-30.8^{\circ} \mathrm{C}$. According to the known relationship between the homogenization temperature of each part and the $\mathrm{CO}_{2}$ phase density, the relative density of the $\mathrm{CO}_{2}$ phase was calculated as c. $0.60-0.82 \mathrm{~g} / \mathrm{cm}^{3}$.

Some measured data for the two-phase aqueous inclusions was also obtained. The complete homogenization temperature is $182.0-240.9^{\circ} \mathrm{C}$, (mean of $206.7^{\circ} \mathrm{C}$ ). The freezing point ranges from -5.6 to $-1.2^{\circ} \mathrm{C}$. The corresponding salinity is $2.07-8.86 \mathrm{wt} \%$ $\mathrm{NaCl}$ equiv., (mean of $4.59 \mathrm{wt} \% \mathrm{NaCl}$ equiv), from the table in BODNAR, (1993).

Polymetallic sulfide stage (IV): the homogenization temperature of the three-phase $\mathrm{CO}_{2}$-rich inclusions varies from 203 $-273{ }^{\circ} \mathrm{C}$, (mean $245.2^{\circ} \mathrm{C}$ ), equalizing to a homogeneous vapour phase. For clathrates with a different phase ratio, they have a similar homogenization temperature. The solid $\mathrm{CO}_{2}$ melting temperature varies from -59.1 to $-56.5 \mathrm{C}$; $\mathrm{CO}_{2}$ clathrate melting temperature is $3.2-7.2^{\circ} \mathrm{C}$. And the corresponding salinity is 5.33 to 11.61 wt $\% \mathrm{NaCl}$ equiv., (average 8.79 wt\% $\mathrm{NaCl}$ equiv.). The par- 


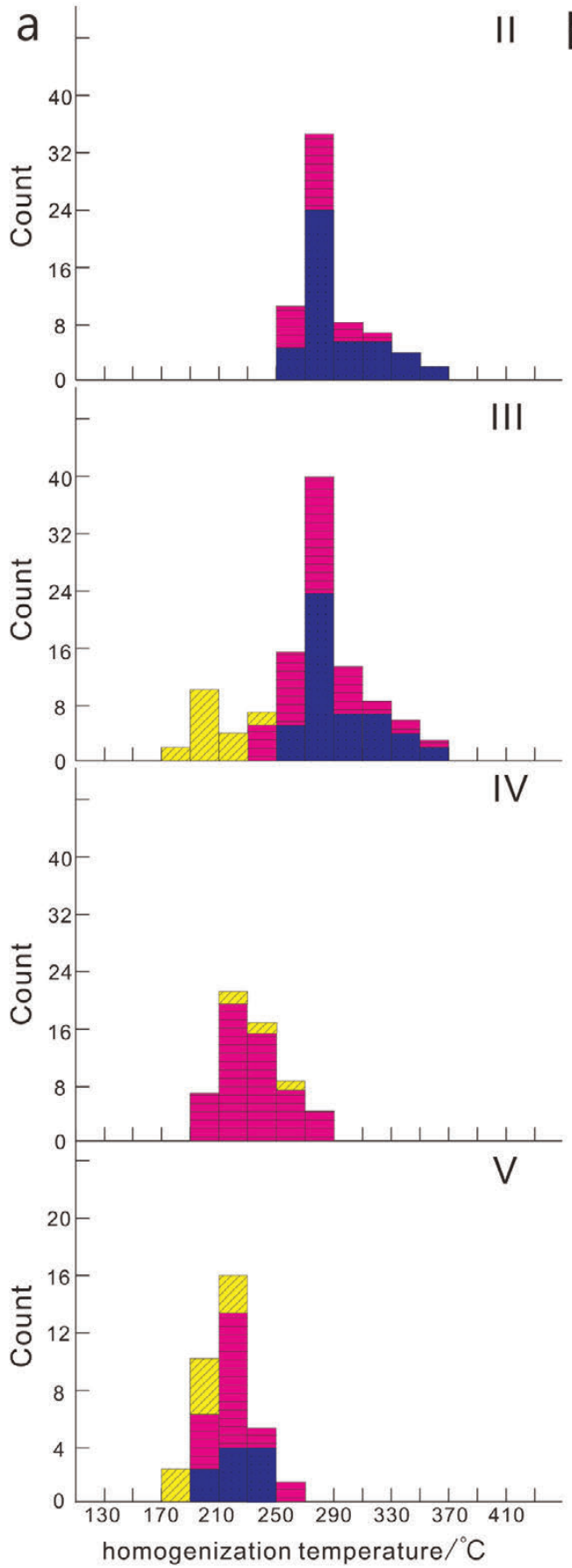

Figure 8. Histograms showing homogenization temperature a) and salinity b).

tial homogenization temperature is $6.1-23.8^{\circ} \mathrm{C}$, and thus the estimated $\mathrm{CO}_{2}$ phase density is c. $0.83-0.97 \mathrm{~g} / \mathrm{cm}^{3}$.

Only 3 two-phase aqueous inclusions, which formed in the same stage as three-phase $\mathrm{CO}_{2}$-rich inclusions, were measured, and their homogenization temperatures are $257.6^{\circ} \mathrm{C}, 238.7{ }^{\circ} \mathrm{C}$, and $240.0^{\circ} \mathrm{C}$, with a mean of $245.4^{\circ} \mathrm{C}$, equalizing to a homogeneous liquid phase. However, at this stage, the homogenization temperature of the three-phase $\mathrm{CO}_{2}$-rich inclusions is concentrated between 235 and $265^{\circ} \mathrm{C}$, with a mean of $245.5^{\circ} \mathrm{C}$, equalizing to a homogeneous vapour phase. The homogenization temperatures of these two are similar. The freezing point of two-phase aqueous inclusions are $-2.0,-0.7$ and $-1.6{ }^{\circ} \mathrm{C}$, with estimated salinities of 3.39, 1.23 and $2.74 \mathrm{wt} \% \mathrm{NaCl}$ equiv., with a mean of $7.85 \mathrm{wt} \% \mathrm{NaCl}$ equiv.

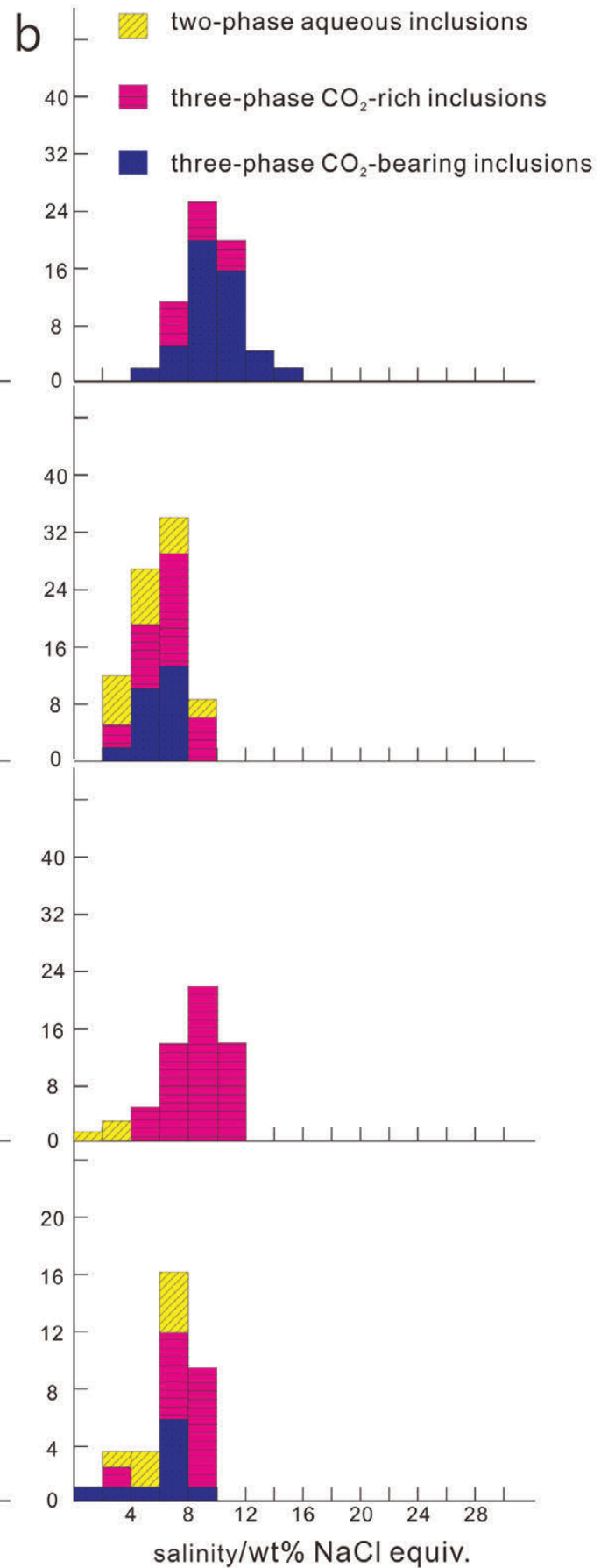

\subsection{Pressure and depth}

To estimate pressure using inclusion mineralization we measured $\mathrm{CO}_{2}$ partial homogenization temperature $\mathrm{T}_{\mathrm{h}}$ with a micro thermometer. Then, according to SHEPHERD et al. (1985), the $\mathrm{CO}_{2}$ phase density $\left(\rho_{\mathrm{Co}_{2}}\right)$ was be determined from a graph of the correlation between homogenization temperature and density. To determine the salinity of the fluid, the $\mathrm{CO}_{2}$ clathrate melting temperature $T_{m, \text { cla, co }}$ is initially measured, followed by measurement of the complete homogenization temperature $\mathrm{T}_{\mathrm{h}}$ of the inclusions. Since the salinity largely influences the pressure estimation, and our measured average salinity at various stages of mineralization of the Fancha gold deposit is nearly $6 \mathrm{wt} \% \mathrm{NaCl}$ equiv., we utilized the correlation graph listed in SCHWARTZ (1989), and checked the $\mathrm{XCO}_{2}-\mathrm{VCO}_{2}-\rho-\mathrm{T}_{\mathrm{h}}$ in $\mathrm{CO}_{2}-\mathrm{H}_{2} \mathrm{O}-\mathrm{NaCl}$ inclusion with 
Table 3. The O-H isotopic compositon of quartz in the Fancha gold deposit.

\begin{tabular}{|c|c|c|c|c|c|c|}
\hline Sample & Host mineral & Stage & $\begin{array}{l}\text { homogenization } \\
\text { temperature } /{ }^{\circ} \mathrm{C}\end{array}$ & $\delta D_{\mathrm{H}_{2} \mathrm{O}}(\% 0)$ & $\delta^{18} \mathrm{O}_{\mathrm{Qz}}(\% 0)$ & $\delta^{18} \mathrm{O}_{\mathrm{H}_{2} \mathrm{O}}(\% 0)$ \\
\hline FX013 & Quartz & 1 & 380 & -87 & 10.8 & 6.28 \\
\hline FX027 & Quartz & $\|$ & 320 & -66.1 & 10.7 & 4.49 \\
\hline FX032 & Quartz & $\|$ & 320 & -58.5 & 10.5 & 4.29 \\
\hline FX015 & Quartz & III & 270 & -53.1 & 10.5 & 2.44 \\
\hline FX016 & Quartz & III & 270 & -54.1 & 11.4 & 3.34 \\
\hline FX028 & Quartz & IV & 240 & -79 & 10.8 & 1.36 \\
\hline
\end{tabular}

$6 \%$ salinity. The resulting $\mathrm{T}_{\mathrm{h}}$ and $\rho_{\mathrm{Co}_{2}}$ values were used to obtain the $\mathrm{XCO}_{2}$ and $\mathrm{VCO}_{2}$. Again, utilizing the graph, we determined the minimum trapping pressure of the inclusion. In this paper, we estimated the pressure by directly choosing inclusions with a salinity of $6 \mathrm{wt} \% \mathrm{NaCl}$ equiv. in nearly all stages. From the graph we estimated the pressure in stage (II) at 120-180MPa; stage (III), $85-140 \mathrm{MPa}$; and stage (IV), $70-120 \mathrm{MPa}$; a declining trend in oreforming pressure. Since in our estimation process, we considered that the ore-forming fluid system is approximated as a $\mathrm{CO}_{2}-\mathrm{H}_{2} \mathrm{O}$ $\mathrm{NaCl}$ system, and ignoring the impact of $\mathrm{CH}_{4}$, our estimation may be slightly different from the actual value. However, since the level of $\mathrm{CH}_{4}$ is rather low, its impact on our estimation is probably trivial.

As the excavation stratum of the Fancha gold deposit is mainly the Taihua Group, we used a rock density of $2.7 \mathrm{~g} / \mathrm{cm}^{3}$ in the lithostatic pressure calculations. The lithostatic pressure depth in the quartz coarse-pyrite stage varies from 4.5 to $6.7 \mathrm{~km}$. In the quartz fine-pyrite stage, it is from 3.5 to $5.2 \mathrm{~km}$, and from 3.5 to $4.0 \mathrm{~km}$ in the quartz polymetallic sulphides stage. In general, the depth decreased as mineralization progressed.

\subsection{Hydrogen and oxygen isotopes}

Hydrogen and oxygen isotope analysis is a reliable method for determining the origin of the mineralising fluid. To determine the ore-forming fluid source of the Fancha gold deposit, samples were collected from all stages (except for the carbonate mineralization stage) for hydrogen and oxygen isotope experiments. The oxygen isotopic composition was obtained using the oxygen isotopic fractionation equilibrium of the mineral and water as follows:

$$
\begin{gathered}
1000 \ln \alpha_{\text {quartz }} \text { - water } \\
\text { (CLAYTON et al., } 1972),
\end{gathered}
$$

where $\mathrm{T}$ is the formation temperature of the mineral, which is the average homogenization temperature of the inclusion.

The $\delta^{18} \mathrm{O}_{\mathrm{H}_{2} \mathrm{O}}$ of metallogenic fluids is between 1.36 and 6.28, and the $\delta \mathrm{D}_{\mathrm{H}_{2} \mathrm{O}}$ is between -87 and -53.1 (Table 3). From stage I to stage IV, the $\delta \mathrm{D}_{\mathrm{H}_{2} \mathrm{O}}$ initially declined and then gradually rose.

\section{DISCUSSION}

\subsection{Diagenesis and mineralization age}

Using multiple techniques, much research has focused on the chronology of the Xiaoqinling gold field (GUO et al., 2009; HE et al., 2009; WANG et al., 2008; ZHANG et al., 2009a). The ${ }^{40} \mathrm{Ar} /{ }^{39} \mathrm{Ar}$ ages of biotite and sericite at the Yangzhaiyu gold deposit area indicate two stages of gold mineralization (LI et al., 2012b), one from 134.5 to $132.3 \mathrm{Ma}$ and the other from 124.3 to 123.7 Ma. In comparison, the ages of gold-bearing quartz veins at the Dongchuang gold deposit exhibit multi-stage mineralization: $142.9 \pm 2.9 \mathrm{Ma}, 132.2 \pm 2.6 \mathrm{Ma}$ and $128.3 \pm 6.2 \mathrm{Ma}$ (sericite ${ }^{40} \mathrm{Ar} /{ }^{39} \mathrm{Ar}$ age) (LI et al., 2002).

REN (2012) suggested that the ${ }^{40} \mathrm{Ar} /{ }^{39} \mathrm{Ar}$ age of the Fancha gold deposit was 130.5 Ma or 120.2 Ma, based on two sericite
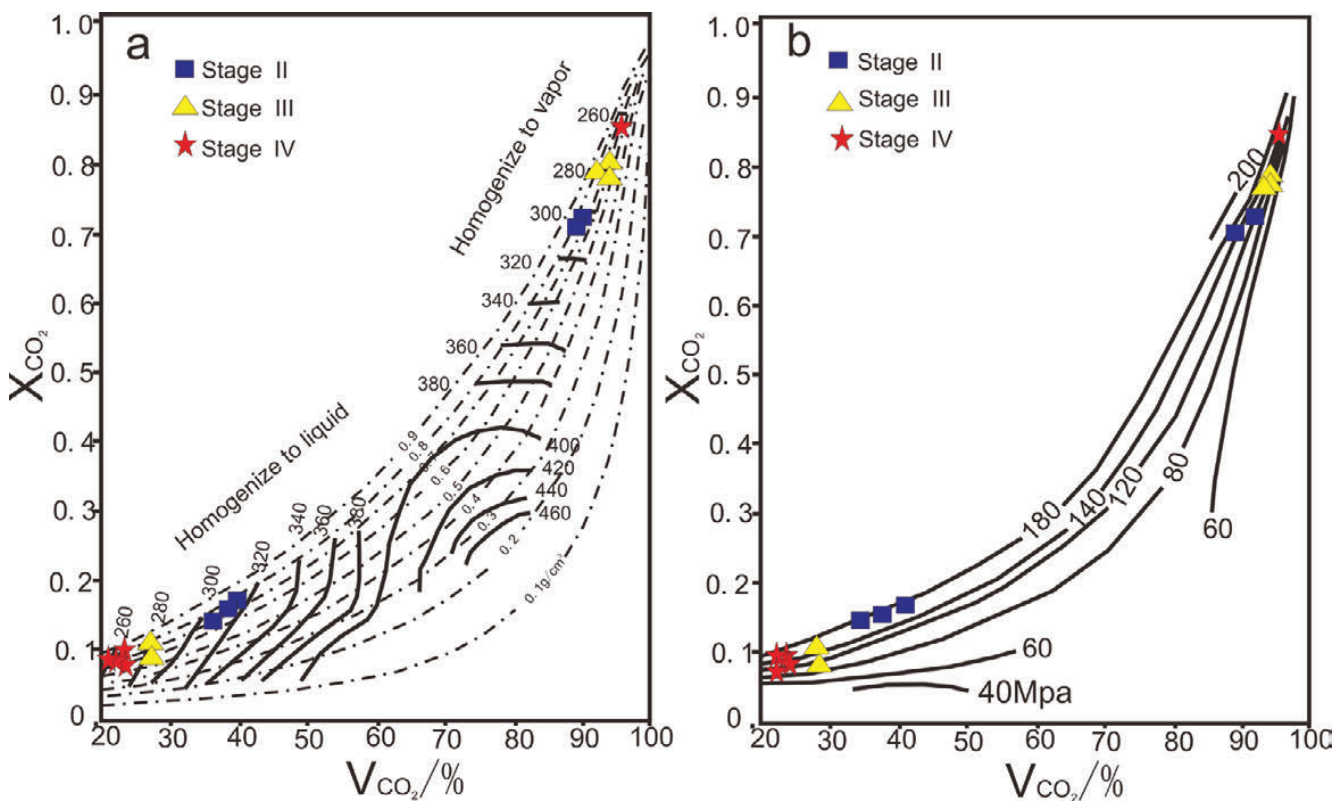

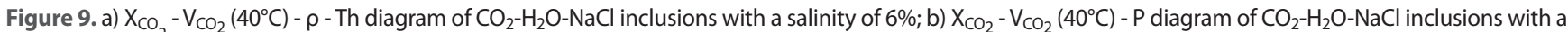
salinity of $6 \%$ (after SCHWARTZ, 1989). 


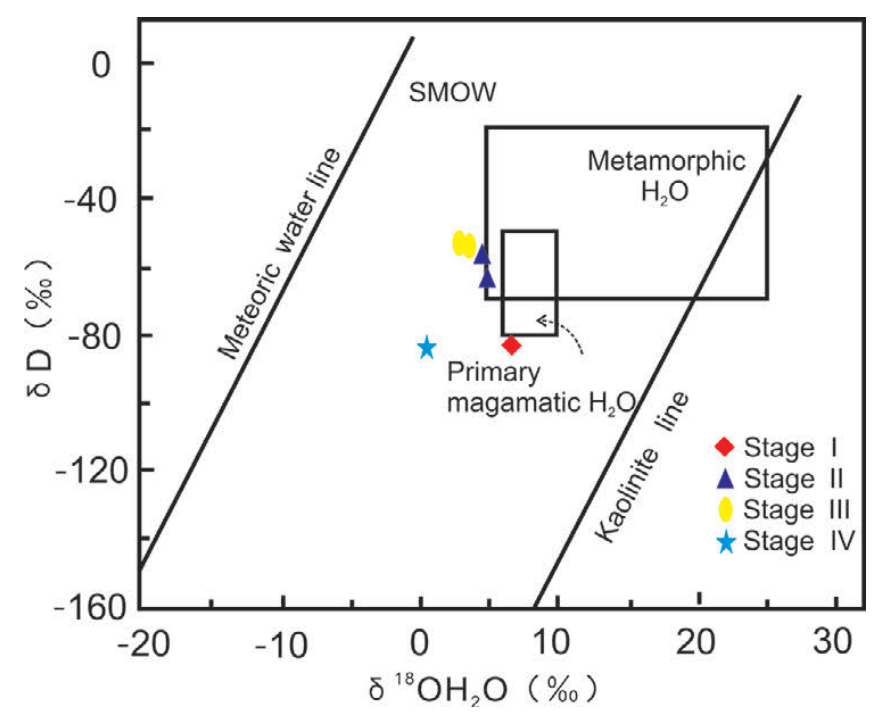

Figure 10. $\delta D_{\mathrm{H}_{2} \mathrm{O}}(\% \mathrm{o})-\delta^{18} \mathrm{O}_{\mathrm{H}_{2} \mathrm{O}}(\% \mathrm{o})$ diagram of the Fancha gold deposit (after TAYLOR, 1974).

samples. These estimates suggest formation in the early Cretaceous, during the Yanshanian period. It is noteworthy that in Yangzhaiyu and Dongchuang, similar gold mineralization events occurred in the same period. Considering the isotopic composition and micro-thermometer evidence of the fluid inclusion data, it can be concluded that the Fancha gold deposit experienced two stages of hydrothermal activity.

\subsection{Metallogenic conditions}

\subsubsection{Geological conditions}

According to previous reports, the main mineral assemblages of the Fancha gold deposit are quartz-pyrite-chalcopyrite, quartzpyrite-chalcopyrite-galena-sphalerite-gold and quartz-carbonatepyrite, of predominantly fine-grained and metasomatic texture. Wall rock alteration mainly includes silicification, beresitization, potash feldspathization and carbonation, where beresitization is an important criterion for ore prospecting. Other studies also show that the Fancha gold deposit belongs to the Yanshanian (REN, 2012), a period when lithospheric thinning and asthenosphere upwelling events occurred very frequently in eastern China (MAO et al., 2010; MAO et al., 2005). In the regional tectonic setting, extension stretch, Archean metamorphic core uplift and granite emplacement resulted in strengthening regional metamorphism, causing formation of metamorphic fluids from early plate collision and continued activity. Activated deep fluids or the early metamorphic fluid rise along the well-formed fracture zone, extracting minerals of the wall rock during migration. Later, they formed into hydrothermal ore and, minerals, resulting in the Taihua Group stratum. The ore-bearing hydrothermal fluid was enriched within the fractures and formed the Fancha gold deposit.

\subsubsection{Metallogenic fluid properties}

Micro-thermometer measurements and petrographic observations show that the Fancha gold mineralization fluid system experienced regular changes: ore-forming fluids from the early stage of a $\mathrm{H}_{2} \mathrm{O}-\mathrm{CO}_{2}-\mathrm{NaCl}$ fluid system to the $\mathrm{CO}_{2}-\mathrm{H}_{2} \mathrm{O}$ fluid system of the main metallogenic stage, and finally evolving into the $\mathrm{H}_{2} \mathrm{O}-\mathrm{NaCl}$ fluid system. From stages II to $\mathrm{V}$, the average homogenization temperature declined from $283.6^{\circ} \mathrm{C}$, to $273.8^{\circ} \mathrm{C}$, to $245.5^{\circ} \mathrm{C}$ and finally $217.7^{\circ} \mathrm{C}$. In general, the fluid salinity was low and changed little (mean 9.24, 6.45, 8.79 and $5.78 \mathrm{wt} \% \mathrm{NaCl}$ equiv., respectively). As discussed above and according to some previous reports, the Fancha ore-forming fluids show the following characteristics:

1. Low homogenization temperatures, between $180{ }^{\circ} \mathrm{C}$ and $360^{\circ} \mathrm{C}$.

2. Low salinity range from 5 to $10 \mathrm{wt} \% \mathrm{NaCl}$ equiv. with little variation.

3. Medium density range from 0.50 to $0.97 \mathrm{~g} / \mathrm{cm}^{3}$, with little variation.

4. Fluid mineralization pressure from 70 to $180 \mathrm{MPa}$, and mineralization depth from 3.5 to $6.7 \mathrm{~km}$.

5. Wall rock alteration including silicification, chlorite and sericitization, and an assumed weakly acidic its ore-forming environment.

In summary, the main metallogenic fluid of the Fancha gold deposit is a low-temperature, low-salinity, medium-density $\mathrm{NaCl}-\mathrm{H}_{2} \mathrm{O}-\mathrm{CO}_{2}$ fluid system. The mineralization environment had low pressure, and was weakly acidic.

\subsubsection{Source of the metallogenic fluid}

The source of the metallogenic fluid is inferred from the hydrogen and oxygen isotope composition of the fluid inclusions. The isotope data of the Fancha gold deposit in various stages of mineralization were mapped on the $\delta^{18} \mathrm{O}_{\mathrm{H}_{2} \mathrm{O}}-\delta \mathrm{D}_{\mathrm{H}_{2} \mathrm{O}}$ diagram (Fig. 10). At only one stage (the quartz feldspar stage), does the data point fall below the primary magmatic water, while for the other stages, namely quartz coarse pyrite and quartz fine pyrite stages, all four data points were located near the left boundary of metamorphic water. The data point of stage (IV) is below the low left boundary of metamorphic water indicating that the metallogenic fluid was mainly metamorphic water (Fig 10). There is a trend towards the meteoric water line, indicating the addition of meteoric fluid.

Furthermore, according to the discussion above, the Fancha gold metallogenic fluids are characterized by low temperature, low salinity and high $\mathrm{CO}_{2}$ levels, in contrast to typical magmatic hydrothermal fluids (high temperature and high salinity). Thus, we suggest that the metallogenic fluid may be hydrothermal fluid of metamorphic origin.

In summary, at the early stages of mineralization, metallogenic fluids were mainly metamorphic fluids, but during the main mineralization stage, the fluid was a mix of metamorphic hydrothermal fluids and meteoric fluids. At the final stage, the fluid is mostly meteoric water.

\subsection{Mineralization process}

\subsubsection{The evolution of the metallogenic fluids}

During the quartz coarse-grained pyrite stage, there were primarily three-phase $\mathrm{CO}_{2}$-bearing inclusions and some three-phase $\mathrm{CO}_{2}$-rich inclusions. The inclusions discovered at the quartz finegrained pyrite stage were mostly three-phase $\mathrm{CO}_{2}$-rich inclusions, three-phase $\mathrm{CO}_{2}$-bearing inclusions and two-phase aqueous inclusions. Petrographic observation shows that three-phase $\mathrm{CO}_{2}$-bearing inclusions with a different vapour-liquid ratio coexisted with the two-phase aqueous inclusions in this stage (Fig. $7 b_{1}-b_{3}$ ). During the polymetallic sulphides stage, three-phase $\mathrm{CO}_{2}$-rich inclusions were dominant, and some other visible inclusions or the same type of inclusions with different vapour-liquid ratios were also observed in the same field of view. The homogenization temperature of inclusions was similar. The fact that inclusions with different gas-liquid ratios have a similar homogenization temperature suggests that in the primary mineralization 


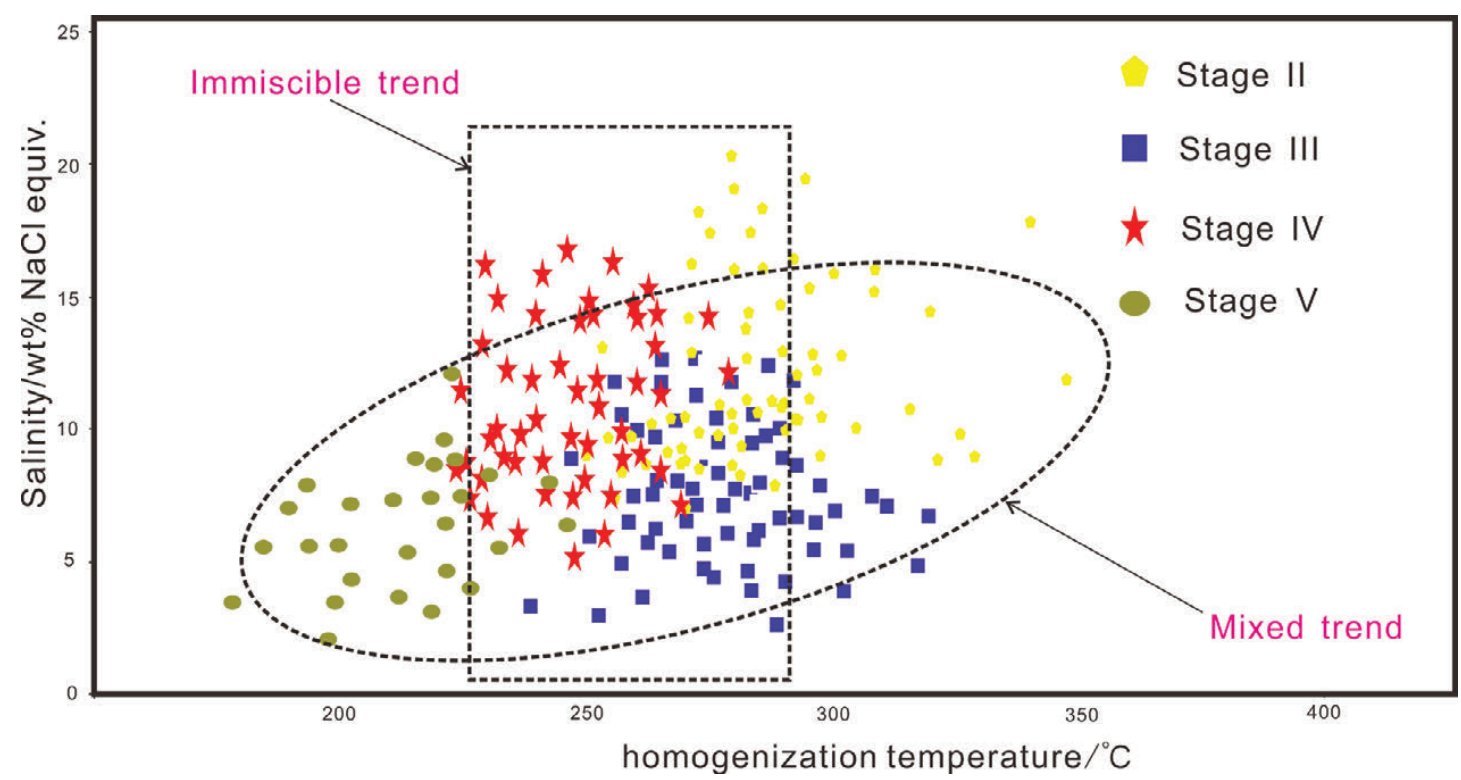

Figure 11. Salinity-homogenization temperature diagram of fluid inclusions in the Fancha gold deposit.

stage, the inclusions were captured in an uneven state (LU, 2004, 2008, 2014). The inclusions in the carbonate stage are generally small and sparsely distributed, and mainly composed of twophase aqueous inclusions and a few three-phase $\mathrm{CO}_{2}$-bearing inclusions. Occasionally three-phase $\mathrm{CO}_{2}$-rich inclusions were also observed. Evidence above reflects both the initial metallogenic fluid of $\mathrm{NaCl}-\mathrm{H}_{2} \mathrm{O}-\mathrm{CO}_{2}$ injected along the fracture, and the subsequent mixing of meteoric fluid leading to a temperature drop. Furthermore, the pressure was reduced due to changes in the tectonic environment. Consequently, fluid immiscibility occurred, characterized by $\mathrm{CO}_{2}$ escaping, and the whole system evolved into a $\mathrm{NaCl}-\mathrm{H}_{2} \mathrm{O}$ and $\mathrm{H}_{2} \mathrm{O}-\mathrm{CO}_{2}$ fluid system.

As can be seen from the salinity/temperature graph (Fig. 11), the inclusion temperatures overlapped and the salinity showed a declining trend. At various stages, mineral compositions represent both different fluid temperatures and crystallized mineral compositions. The results also show that declining salinity has a positive effect on the crystallization of the minerals. In addition, from the microscopic temperature measurement, we observed combinations of the same salinity but different temperatures, or of different salinities but the same temperature. At the quartz fine-grain pyrite stage, the quartz polymetallic sulfide stage, and the main metallogenic stage, the salinity data are clearly separated into low and high salinity groups, suggesting immiscibility of the ore-forming fluids. That, together with the hydrogen and oxygen isotope results, suggests that in the early stage, fluids were metamorphic and hydrothermal, of low temperature, and high salinity. In the primary mineralization stage, the main fluids were metamorphic hydrothermal fluid mixed with meteoric water. In the late mineralization stage, the main fluids were meteoric water of low-temperature and low-salinity.

\subsubsection{The gold mineralization mechanism}

Boiling and fluid immiscibility are considered to be the main gold precipitation mechanisms in many deposits. Boiling should have the following indicators: (1) explosive breccia exists in ore bodies; (2) gas-liquid ratio and homogeneous temperature of inclusions vary greatly in the same stage (HAYBA et al., 1986). There is no obvious sign of boiling in the Fancha gold deposit, and the existence of multi-stage fluids can be seen in field observations. As discussed earlier, the homogenization temperature of the fluid inclusions in the deposit is low and has shown little change. Therefore, this paper explains the enrichment of gold in the deposit from the point of view of fluid immiscibility.
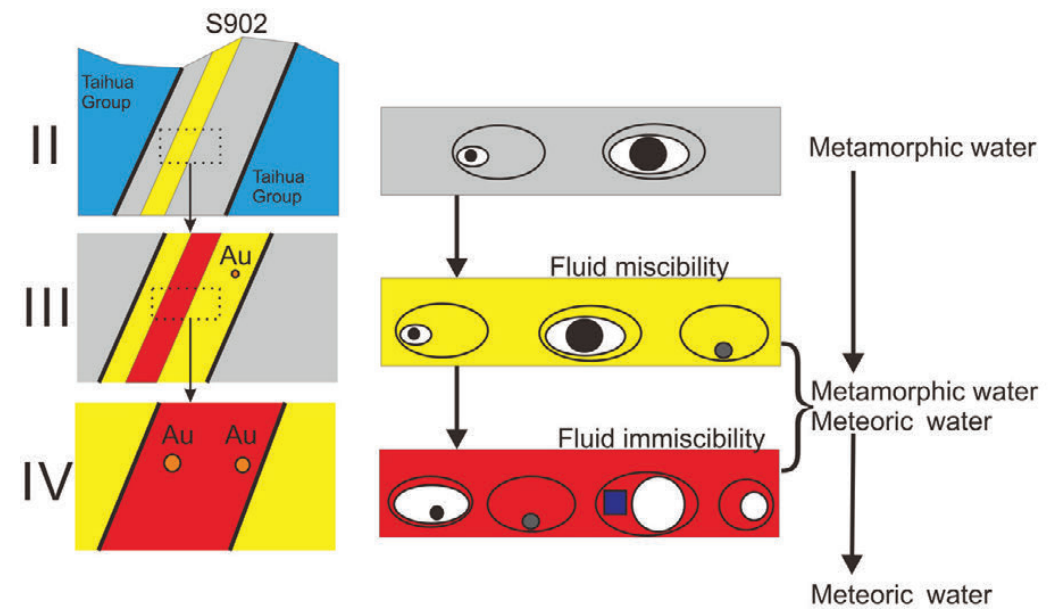

Figure 12. Schematic diagram of metallogenic model of the Fancha gold deposit. 
The coexistence of two or more fluids in a system is called the immiscibility of fluids (LU, 2004; ROEDDER, 1992). Scholars discovered the mineralization of hydrothermal gold deposits is closely related to the immiscibility of $\mathrm{H}_{2} \mathrm{O}-\mathrm{CO}_{2}-\mathrm{NaCl}$ fluid (CRAW, 1992; HU et al., 2005; LU, 2014). Immiscibility causes a phase separation of the single fluid phase, breaking the balance of the original fluid system, resulting in precipitation of valuable components.

Microscopic observation of the Fancha gold deposit inclusions shows a group of primary inclusions (formed simultaneously at a single mineral, including two-phase aqueous inclusions, three-phase $\mathrm{CO}_{2}$-bearing inclusions and three-phase $\mathrm{CO}_{2}$-rich inclusions) can co-exist in the same field of view, although the filling degree is very different. They formed a continuous series, and occasionally there are daughter mineral-bearing inclusions. The above phenomenon illustrates the petrographic characteristics of fluid immiscibility.

At the primary mineralization stage, there are two-phase $\mathrm{CO}_{2}$-bearing inclusions and three-phase $\mathrm{CO}_{2}$-rich inclusions with different vapour-liquid ratios. While these two types of inclusions have different means of homogenization, their homogenization temperatures are similar. For the polymetallic sulfide stage, the homogenization temperature of three two-phase aqueous inclusions is $257.6{ }^{\circ} \mathrm{C}, 238.7^{\circ} \mathrm{C}$ and $240.0^{\circ} \mathrm{C}$, with a mean of $245.4^{\circ} \mathrm{C}$, equalizing to a liquid phase. The homogenization temperature of two-phase $\mathrm{CO}_{2}$-rich inclusions ranges from 235 to $265^{\circ} \mathrm{C}$, with an average of $245.5^{\circ} \mathrm{C}$, equalizing to a vapour phase. These two inclusions formed at the same time but with different end-members, and with similar homogenization temperatures but different means of homogenization. Considering both the definition of immiscible inclusions and the microscopic features of the observed inclusions, it can be concluded that they are immiscible inclusions. Fluid immiscibility is the main metallogenic mechanism of the Fancha gold deposit.

Furthermore, H-O isotope mapping (Fig. 10) and the homogenization temperature-salinity data (Fig. 11), suggest that metallogenic fluids in the primary mineralization stage were mixed significantly with meteoric water. Therefore, the mixture of fluids may also be one of the metallogenic mechanisms for the Fancha gold deposit.

\subsubsection{The metallogenic process}

Geological and mineralogical data presented here support a preliminary idealized fluid-based mineralization model for the Fancha gold deposit.

The Fancha gold deposit is located in the North China Craton. The collision of the Yangtze and North China Cratons occurred 245-210Ma ago (AMES et al., 1993; LI et al., 2011). At the end of the mid-Triassic, the strong compressional environment led to different degrees of metamorphic deformation of the strata. Severe dehydration of a large number of water-bearing minerals resulted in the formation of metamorphic hydrothermal fluid with $\mathrm{K}$, $\mathrm{Na}$ and $\mathrm{Si}$, and various volatiles. The metallogenic hydrothermal fluid rose along fractures, accompanied by a potash alteration that is closely related to the gold-bearing quartz veins (stage I).

With the Qinling Orogenic Belt thrust from north to south, the strata experienced varying degrees of deterioration and deformation, and metamorphic fluids were formed once again (CHEN et al., 1998; MAO et al., 2005). As the temperature declined in the high-pressure ductile shear environment, metamorphic fluids rich in $\mathrm{CO}_{2}$ and other volatiles formed large, weakly mineralized milky quartz veins in some parts (stage II). Fluid inclusions were mainly highly filled three-phase $\mathrm{CO}_{2}$-bearing inclusions and some three-phase $\mathrm{CO}_{2}$-rich inclusions.

Large quartz veins that formed early, developed a series of small fractures due to tectonic stress. Ore-bearing metamorphic hydrothermal fluid and some meteoric water filled the fractures, forming fine-pyrite smoky quartz veins (stage III). In this stage, the main inclusions are three-phase $\mathrm{CO}_{2}$-rich inclusions, threephase $\mathrm{CO}_{2}$-bearing inclusions and two-phase aqueous inclusions. Fluid mixing may have occurred in this stage.

In the late mineralization stage, a small amount of metamorphic fluid and meteoric water mixed and filled the fractures of the silica fine-pyrite veins, forming polymetallic sulphide veins (stage IV). At this stage, the main inclusions were three-phase $\mathrm{CO}_{2}$-rich inclusions and two-phase aqueous inclusions; different types of inclusions but with similar homogenization temperature. For the same type of inclusions, the gas-liquid ratio continuously changes. At this stage, the tectonic environment altered from compressive to tensile, and the decompression caused the original fluid to decompress and potentially boil. In addition, the mixture of meteoric water caused the temperature of the original high-temperature metallogenic fluid to decline, resulting in immiscibility of the fluid. The metallogenic fluid is separated from the $\mathrm{NaCl}-\mathrm{H}_{2} \mathrm{O}-\mathrm{CO}_{2}$ fluid system into $\mathrm{H}_{2} \mathrm{O}-\mathrm{NaCl}$ and $\mathrm{CO}_{2}-\mathrm{H}_{2} \mathrm{O}$ fluid system, with $\mathrm{CO}_{2}$ acting as a $\mathrm{pH}$ buffer in the metallogenic fluid. The metallogenic elements are in a weak acid environment. The Au-S complex had the highest solubility (LU, 2008), then $\mathrm{CO}_{2}$ escape caused Au to precipitate from the fluid. The immiscibility caused the metallogenic material to precipitate and be enriched at favourable locations.

As the meteoric water continued mixing, the fluid properties changed further. The temperature and pressure continued to decline, associated with further escape of $\mathrm{CO}_{2}$. In the late mineralization stage, meteoric water formed some weakly developed carbonate veins (stage $\mathrm{V}$ ).

\section{CONCLUSIONS}

Both detailed field investigations and laboratory research were undertaken on the Fancha gold deposit. The geological characteristics of the deposit were identified and insights into the fluid inclusions at various stages of mineralization in terms of petrography, thermometry and stable isotope geochemistry were obtained. The main conclusions are:

1. The Fancha gold deposit is a typical quartz vein type gold deposit in the Xiaoqinling gold field. The main ore minerals are pyrite, chalcopyrite, native gold, sphalerite and galena, gangue minerals include quartz and calcite. According to the combination of minerals and vein interpenetration, the metallogenic process can be divided into five metallogenic stages: the quartz-K-feldspar (I), quartz-coarse pyrite (KAGAMI et al., 1995), quartz-fine pyrite (III), quartz-polymetallic sulfide (IV) and carbonate stages (V). Gold was mainly precipitated in stages III and IV.

2. The petrographic observations of fluid inclusions show that in the Fancha gold deposit, there are mainly three-phase $\mathrm{CO}_{2}$ bearing, three-phase $\mathrm{CO}_{2}$-rich and two-phase aqueous inclusions. Regarding the composition of inclusions, there are mainly threephase $\mathrm{CO}_{2}$-bearing and a few three-phase $\mathrm{CO}_{2}$-rich inclusions in stage II; mainly three-phase $\mathrm{CO}_{2}$-bearing inclusions, two-phase aqueous inclusions and a small amount of three-phase $\mathrm{CO}_{2}$-rish inclusions in stage III; in stage IV, the main types are three-phase $\mathrm{CO}_{2}$-rich and a few two-phase aqueous inclusions; for stage $\mathrm{V}$ the main ones are two-phase aqueous, a small number of twophase $\mathrm{CO}_{2}$-bearing and three-phase $\mathrm{CO}_{2}$-rich inclusions. 
3. The fluid inclusions temperature data show that metallogenic fluids are generally of low temperature and salinity, features of $\mathrm{CO}_{2}$-rich metamorphic fluids. In the early mineralization stage, the main fluids were metamorphic water, while in the primary mineralization stage, the main fluids were mixtures of metamorphic and meteoric water. In the late stage, most fluids were meteoric water.

4. The immiscibility and mixing of fluids are the primary precipitation mechanisms of the Fancha gold deposit.

\section{REFERENCES}

AMES, L., TILTON, G.R. \& ZHOU, G.Z. (1993): Timing of collision of the Sino-Korean and Yangtze Cratons - U-Pb zircon dating of coesite-Bearing eclogites.- Geology, 21/4, 339-342. doi: 10.1130/0091-7613(1993)021<0339:Tocots $>2.3 . C o ; 2$

BODNAR, R.J. (1993): Revised equation and table for determining the freezing-point depression of $\mathrm{H}_{2} \mathrm{O}-\mathrm{Nacl}$ solutions.- Geochim. Cosmochim. Acta, 57/3, 683-684. doi: 10.1016/0016-7037(93)90378-A

CHEN, Y.J. (2013): The development of continental collision metallogeny and its application.-Acta Petrologica Sinica, 29/1, 1-17.

CHEN, Y.J., GUO, G.J. \& LI, X. (1998): Metallogenic geodynamic background of Mesozoic gold deposits in granite-greenstone terrains of North China Craton.-Sci China Ser D, 41/2, 113-120. doi: 10.1007/bf02932429

CHEN, Y.J., NI, P., FAN, H.R., PIRAJNO, F., LAI, Y., SU, W.C. \& ZHANG, H. (2007): Diagnostic fluid inclusions of different types hydrothermal gold deposits.- Acta Petrologica Sinica, 23/9, 2085-2108. doi: 10.3969/j.issn.1000-0569.2007.09.009

CHEN, Y.J., PIRAJNO, F. \& QI, J.P. (2008): The Shanggong gold deposit, Eastern Qinling Orogen, China: Isotope geochemistry and implications for ore genesis.- J. Asian Earth Sci., 33/3-4, 252-266. doi: 10.1016/j.jseaes.2007.12.002

CHI, G.X. \& LU, H.Z. (2008): Validation and representation of fluid inclusion microthermometric data using the fluid inclusion assemblage (FIA) concept.- Acta Petrologica Sinica, 24/9, 1945-1953. doi: 10.1134/S0869593808050109

CLAYTON, R.N., O’NEIL, J.R. \& MAYEDA, T.K. (1972): Oxygen Isotope exchange between quartz and water.- Journal of Geophysical Research, 77/17, 3057-3067. doi: 10.1029/JB077i017p03057

COLLINS, P.L.F. (1979): Gas hydrates in $\mathrm{CO}_{2}$ - bearing fluid inclusions and the use of freezing data for estimation of salinity.- Economic Geology, 74/6, 1435-1444. doi: 10.2113/gsecongeo.74.6.1435

CRAW, D. (1992): Fluid evolution, fluid immiscibility and gold deposition during Cretaceous recent tectonics and uplift of the Otago and Alpine Schist, New-Zealand.Chem. Geol., 98/3-4, 221-236. doi: 10.1016/0009-2541(92)90186-9

DING, T.P. (1980): Hydrogen and oxygen isotope geochemistry, Geological Publishing House, Beijing.

FAN, H.R., XIE, Y.H., ZHAI, M.G. \& JIN, C.W. (2003): A three stage fluid flow model for Xiaoqinling lode gold metallogenesis in the He' nan and Shaanxi provinces, central China.- Acta Petrologica Sinica, 19/2, 260-266. doi: 10.3969/j. issn.1000-0569.2003.02.007

FAN, H.R., XIE, Y.H., ZHAO, R. \& WANG, Y.L. (2000a): Dual origins of Xiaoqinling gold-bearing quartz veins: Fluid inclusion evidence.- Chinese Sci. Bull., 45/15, 1424-1430. doi: 10.1007/bf02886252

FAN, H.R., XIE, Y.H., ZHENG, X.Z. \& WANG, Y.L. (2000b): Ore-forming fluids in hydrothermal breccia-related gold mineralization in Qiyugou, Henan Province.Acta Petrologica Sinica, 16/4, 559-563. doi: 10.3969/j.issn.1000-0569.2000.04.015

FENG, J.Z., ZHANG, D.T., ZHANG, W.M., WANG, X.C., CUI, X.X., LIU, Z.Y. \& WANG, Z.Q. (2014): REE Geochemical characteristics of Xiaoqinling gold deposits and their geological significance.- Geoscience, 28/6, 1151-1160. doi: 10.3969/j.issn.1000-8527.2014.06.005

GAO, X.Y., ZHAO, T.P., GAO, J.F., XUE, L.W. \& YUAN, Z.L. (2012): LA-ICP-MS zircon $\mathrm{U}-\mathrm{Pb}$ ages,Hf isotopic composition and geochemistry of adakitic granites in the Xiaoqinling region,the south margin of the North China block.- Geochimica, 41/4, 303-325. doi: 10.19700/j.0379-1726.2012.04.002

GOLDSTEIN, R.H. (2001): Fluid inclusions in sedimentary and diagenetic systems.Lithos, 55/1-4, 159-193. doi: 10.1016/s0024-4937(00)00044-X

GUO, B., ZHU, L.M., LI, B., GONG, H.J. \& WANG, J.Q. (2009): Zircon U-Pb age and Hf isotope composition of the Huashan and Heyu granite plutons at the southern margin of North China Craton: Implications for geodynamic setting.- Acta Petrologica Sinica, 25/2, 265-281.

HAYBA, D.O., FOLEY, N.K. \& HEALDWETLAUFER, P. (1986): Characteristics that distinguish types of epithermal deposits.- J. Geochem. Explor., 25/1-2, 231-231. doi: 10.1016/0375-6742(86)90016-6

HE, Y.H., ZHAO, G.C., SUN, M. \& XIA, X.P. (2009): SHRIMP and LA-ICP-MS zircon geochronology of the Xiong'er volcanic rocks: Implications for the Paleo-Mesoproterozoic evolution of the southern margin of the North China Craton.- Precambrian Res., 168/3-4, 213-222. doi: 10.1016/j.precamres.2008.09.011
HU, F.F., FAN, H.R., SHEN, K., ZHAI, M.G., JIN, C.W. \& CHEN, X.S. (2005): Nature and evolution of ore-forming fluids in the Rushan lode gold deposit, Jiaodong peninsula of eastern China.-Acta Petrologica Sinica, 21/5, 1329-1338. doi: 10.3969/j. issn.1000-0569.2005.05.002

KAGAMI, H., YUHARA, M., TAINOSHO, Y., IIZUMI, S., OWADA, M. \& HAYAMA, Y. (1995): Sm-Nd Isochron Ages of Mafic Igneous Rocks from the Ryoke Belt, Southwest Japan - Remains of Jurassic Igneous Activity in a Late Cretaceous Granitic Terrane.- Geochem. J., 29/2, 123-135. doi: DOI 10.2343/geochemj.29.123

LI, J.W., BI, S.J., SELBY, D., CHEN, L., VASCONCELOS, P., THIEDE, D., ZHOU, M.F., ZHAO, X.F., LI, Z.K. \& QIU, H.N. (2012a): Giant Mesozoic gold provinces related to the destruction of the North China craton.- Earth Planet. Sc. Lett., 349, 26-37. doi: 10.1016/j.eps1.2012.06.058

LI, J.W., LI, Z.K., ZHOU, M.F., CHEN, L., BI, S.J., DENG, X.D., QIU, H.N., COHEN, B., SELBY, D. \& ZHAO, X.F. (2012b): The early Cretaceous Yangzhaiyu lode gold deposit, North China Craton: a link between craton reactivation and gold veining.- Economic Geology, 107/1, 43-79. doi: 10.2113/econgeo.107.1.43

LI, N., CHEN, Y.J., FLETCHER, I.R. \& ZENG, Q.T. (2011): Triassic mineralization with Cretaceous overprint in the Dahu Au-Mo deposit, Xiaoqinling gold province: Constraints from SHRIMP monazite U-Th-Pb geochronology.- Gondwana Res., 20/2-3, 543-552. doi: 10.1016/j.gr.2010.12.013

LI, Q.Z., CHEN, Y.J., ZHONG, Z.Q., LI, W.L., LI, S.R., GUO, X.D. \& JIN, B.Y. (2002): ${ }^{40} \mathrm{Ar}-{ }^{39} \mathrm{Ar}$ dating on the metallogenesis of the Dongchuang gold deposit in the $\mathrm{Xi}$ aoqinling area.- Acta Geol Sin-engl, 76/4, 488-493.

LI, S.M., QU, L.Q., SU, Z.B., HUANG, J.J., WANG, X.S. \& YUE, Z.S. (1996): Geology and Metallogenic Prognosis of Gold Deposits in the Xiaoqinling District, Geological Publishing House, Beijing, $250 \mathrm{p}$

LU, H.Z. (2004): Fluid Inclusions, Science Press, Beijing, 487 p

-(2008): Role of $\mathrm{CO}_{2}$ fluid in the formation of gold deposits: Fluid inclusion evidences.Geochimica, 37/4, 321-328. doi: 10.19700/j.0379-1726.2008.04.004

- (2014): Fluid inclusion petrography:a discussion.- Geological Journal of China Universities, 20/2, 177-184. doi: 10.16108/j.issn1006-7493.2014.02.003

LU, H.Z., ZHU, X.Q., SHAN, Q. \& WANG, Z.G. (2013): Hydrothermal evolution of gold-bearing pyrite and arsenopyrite from different types of gold deposits.-Mineral Deposits, 32/4, 823-842. doi: 10.16111/j.0258-7106.2013.04.014

LU, X.X., WEI, X.D., YU, Z.P. \& YE, A.W. (2003): Characteristics of ore-forming fluids in gold deposits of Xiaoqinling-Xiong'ershan area.- Mineral Deposits, 22/4, 377-385. doi: 10.16111/j.0258-7106.2003.04.007

LUAN, S.W., CAO, D.C., FANG, Y.K. \& WANG, J.Y. (1985): Geochemistry of Xiaoqinling gold deposits.- Journal of mineralogy and petrology, 02, 2-7. doi: 10.19719/j.cnki.1001-6872.1985.02.001

LUAN, S.W. \& CHEN, S.D. (1990): Main ore controlling factors and metallogenic model of gold deposits in xiaoqinling area.- Contributions to Geology and Mineral Resources Research/4, 1-14.

MAO, J.W., GOLDFARB, R.J., ZHANG, Z.W., XU, W.Y., QIU, Y.M. \& DENG, J. (2002): Gold deposits in the Xiaoqinling-Xiong'ershan region, Qinling Mountains, central China.-Miner. Deposita, 37/3-4, 306-325. doi: 10.1007/s00126-001-02481

MAO, J.W., XIE, G.Q., PIRAJNO, F., YE, H.S., WANG, Y.B., LI, Y.F., XIANG, J.F. \& ZHAO, H. J. (2010): Late Jurassic-Early Cretaceous granitoid magmatism in Eastern Qinling, central-eastern China: SHRIMP zircon U-Pb ages and tectonic implications.- Aust. J. Earth Sci., 57/1, 51-78. doi: 10.1080/08120090903416203

MAO, J.W., XIE, G.Q., ZHANG, Z.H., LI, X.F., WANG, Y.T., ZHANG, C.Q. \& LI, Y.F. (2005): Mesozoic large-scale metallogenic pulses in North China and corresponding geodynamic settings.-Acta Petrologica Sinica, 21/1, 169-188. doi: 10.3321/j. issn: 1000-0569.2005.01.017

MELFOS, V. \& VOUDOURIS, P. (2016): Fluid evolution in Tertiary magmatic-hydrothermal ore systems at the Rhodope metallogenic province, NE Greece. A review.Geologia Croatica, 69/1, 157-167. doi: 10.4154/gc.2016.12

NI, S.J. (1994): A new model of gold mineralization with the contribution of meso-basic dyke rocks in Xiaoqinling, Southwest Jiaotong University Press, Chengdu, 136 p.

NIE, F.J., JIANG, S.H. \& ZHAO, Y.M. (2001): Lead and sulfur isotopic studies of the Wenyu and the Dongchuang quartz vein type gold deposits in Xiaoqinling area, Henan and Shaanxi Provinces, central China.- Mineral Deposits, 20/2, 163-173. doi: 10.16111/j.0258-7106.2001.02.009

QI, J.P., CHEN, Y.J. \& LI, Q.Z. (2002): Synthesis of hydrothermal metallogenesis in Xiaoqinling orogenic gold field.- Mineral Deposits/A1, 1009-1012. doi: 10.16111/ j.0258-7106.2002.s1.260

REN, Z.Y. (2012): Mineralization characteristic and genesis of the Fancha and Yisishan gold deposit in the eastern Xiaoqinling district [Master Mineral deposits]: China University of Geosciences (Wuhan), 106 p.

ROEDDER, E. (1984): Fluid Inclusions.- Rev. Mineral, 12, 1-\&.

- (1992): Fluid inclusion evidence for immiscibility in magmatic differentiation, 5-20 p. SCHWARTZ, M.O. (1989): Determining phase volumes of mixed $\mathrm{CO}_{2}-\mathrm{H}_{2} \mathrm{O}$ inclusions using microthermometric measurements.- Miner. Deposita, 24/1, 43-47.

SHEPHERD, T.J., RANKIN, A.H. \& ALDERTON, D.H.M. (1985): A practical guide to fluid inclusion studies Blackie Academic \& Professional, London. 
TASEV, G., SERAFIMOVSKI, D. \& SERAFIMOVSKI, T. (2018): Evolution of oreforming fluids in the Bukovik-Kadiica porphyry $\mathrm{Cu}$ deposit, Republic of Macedonia.- Geologia Croatica, 71/1, 1-18. doi: 10.4154/gc.2018.01

TOURET, J.L.R. (2001): Fluids in metamorphic rocks.- Lithos, 55/1-4, 1-25. doi: 10.1016/s0024-4937(00)00036-0

WANG, T.H., MAO, J.W. \& WANG, Y.B. (2008): Research on SHRIMP U-Pb chronology in Xiaoqinling-Xionger' shan area: the evidence of delamination of lithosphere in Qinling orogenic belt.-Acta Petrologica Sinica, 24/6, 1273-1287.

WANG, Y.T., YE, H.S., YE, A.W., SHUAI, Y., LI, Y.G. \& ZHANG, C.Q. (2010): Zircon SHRIMP U-Pb ages and their significances of the Wenyu and Niangniangshan granitic plutons in the Xiaoqinling area, central China.-Scientia Geologica Sinica, 45/1, 167-180. doi: 10.3969/j.issn.0563-5020.2010.01.015

WANG, Z.W. \& ZHOU, Y.Z. (1996): The characteristic and geological significance of ore-forming fluid of gold deposits in Xiaoqinling area.- Bulletin of Mineralogy Petrology and Geochemistry, 15/4, 225-227.

XU, X.S., GRIFFIN, W.L., MA, X., O’REILLY, S.Y., HE, Z.Y. \& ZHANG, C.L. (2009): The Taihua group on the southern margin of the North China craton: further insights from U-Pb ages and Hf isotope compositions of zircons.- Miner. Petrol., 97/1-2, 43-59. doi: 10.1007/s00710-009-0062-5
ZHANG, D.Q., SHE, H.Q., FENG, C.Y., LI, D.X. \& LI, J.W. (2009a): Geology, age, and fluid inclusions of the Tanjianshan gold deposit, western China: Two orogenies and two gold mineralizing events.- Ore Geol. Rev., 36/1-3, 250-263. doi: 10.1016/j.oregeorev.2009.06.002

ZHANG, Y.H., MAO, J.W., ZONGYAN, L.I., CUIJIE, Q., ZHANG, X.M. \& ZHANG, X.W.I. (2009b): Ore Deposit Types and Characteristics of Magmatic-Hydrothermal Systems and Implication for Exploration.-Acta Geologica Sinica, 83/3, 399-425. doi: 10.3321/j.issn:0001-5717.2009.03.009

ZHAO, H.X., JI, J., ZHAO, Z., CHEN, J.S. \& LI, B. (2017): Fluid Inclusion Characteristics and Ore Genesis of the Dahu Gold and Molybdenum Deposits in the Xiaoqinling Gold Belt.- Geological Journal of China Universities, 23/1, 72-82. doi: 10.16108/j.issn1006-7493.2015122

ZHOU, Z.J., CHEN, Y.J., JIANG, S.Y., HU, C.J., QIN, Y. \& ZHAO, H.X. (2015): Isotope and fluid inclusion geochemistry and genesis of the Qiangma gold deposit, Xiaoqinling gold field, Qin ling Orogen, China.- Ore Geol. Rev., 66, 47-64. doi: 10.1016/j.oregeorev.2014.10.020

ZHOU, Z.J., CHEN, Y.J., JIANG, S.Y., ZHAO, H.X., QIN, Y. \& HU, C.J. (2014): Geology, geochemistry and ore genesis of the Wenyu gold deposit, Xiaoqinling gold field, Qinling Orogen, southern margin of North China Craton..- Ore Geol. Rev., 59, 1-20. doi: 10.1016/j.oregeorev.2013.12.001 